\title{
"Headship": Making the Case for Fruitful Equality in a World of Indifferent Sameness and Unbridgeable Difference
}

\author{
Margaret Harper McCarthy
}

Pontifical John Paul II Institute for Studies on Marriage and Family, Catholic University of America, Washington, DC 20910, USA; mmccarthy@johnpaulii.edu

Received: 7 April 2020; Accepted: 19 May 2020; Published: 16 June 2020

check for updates

\begin{abstract}
The article takes up the biblical category of "headship," one of the "third rails" for Christians in a context dominated by the limited conceptions of equality, especially those assumed by "second wave" and "difference" feminism, viz., that of interchangeable sameness and unbridgeable difference. Headship is easily dismissed as an instance of (bad) cultural influence that spoiled Christianity's egalitarian beginnings. Less radically, headship is simply avoided, or glossed over with apologetic caveats. Headship is an embarrassment, because it suggests not only exclusive differences-the "head" is not the "body"- but an order between them. Head and body are "subject to each other" in distinct and coordinated ways. In what follows, the author claims that headship is not only not an affront to equality, but its very condition between subjects who belong to each other in a generous relation of reciprocal and fruitful unity and distinction. Moreover, it is the expression of the novelty of Christianity, regarding first of all the nature of God in whom there is an original Head, and a "positive other," without any hint of subordinationism (inequality). On the contrary, the Father is never absolute, but always already determined by the Son. This original headship then informs the Christian conception of the world, its positivity, even to the point that it can give something to God. Finally, it informs the this-worldly headships (Christ-Church and husband-wife). There, headship counters the status quo, by countering the "body's" default immanentistic "certainty" about her exclusive life-giving power, enjoining her to acknowledge a transcendent source. It restores equality to the head. For the "head," it counters the false absolutist image of God, while enjoining him to "radiate" something of which he is first "subject," to "be involved with," and determined by, the woman, as a positive other. It restores equality to the body. In sum, the article urges us to turn towards the deepest resources of Christianity, to find therein a more fruitful equality.
\end{abstract}

Keywords: headship; feminism; goddess feminism; fatherhood; motherhood; order; difference; sameness; equality

\section{Introduction}

To a feminist, there is nothing so loathsome as an order between man and woman. The idea immediately suggests a relation between a superior and an inferior, a norm and its aberration, a primary and a second best, between two who are, in sum, not equals. This objection is most notably expressed by the author of The Second Sex, when she turns to the Biblical expression of that order in the second chapter of Genesis. To Simone de Beauvoir, the emergence of Eve from Adam's side suggests something far worse than the master-slave dialectic. For there, the woman never acquires reciprocal recognition as a free individual by the man (as the slave does). The man, who cannot sustain the constant effort of accomplishing himself in solitude-staying clear of the inexorable dialectic that springs from the reciprocity of freedoms- "falls back" on the woman, who is the perfect solution, because she is both a 
peer (with consciousness), and yet also foreign to him (as nature). She pits neither the "hostile silence of nature nor the hard demand of a reciprocal recognition against him." ${ }^{1}$. He possesses her, thus, and only to confirm his (essential) being by projecting on to her all of his own carnal (inessential) finitude, and confirming his freedom, through her docility. ${ }^{2}$ The movement is not reciprocated. Commenting on Genesis, she says:

Eve was not formed at the same time as man; she was not made either from a different substance or from the same clay that Adam was modeled from: she was drawn from the first male's flank. Even her birth was not autonomous; God did not spontaneously choose to create her for herself and to be directly worshipped in turn: he destined her for man; he gave her to Adam to save him from loneliness, her spouse is her origin and her finality; she is his compliment in the inessential mode. Thus, she appears a privileged prey. She is nature raised to the transparency of consciousness; she is a naturally submissive consciousness. And therein lies the marvelous hope that man has often placed in woman: he hopes to accomplish himself as being though carnally possessing a being while making confirmed in his freedom by a docile freedom." ${ }^{3}$

Given this account of the relation between man and woman, it is no wonder that De Beauvoir's post-modern younger sisters moved to eliminate the very possibility of any intrinsic and positive relation at all. Correcting the egalitarian "second wave" feminists, who sought equality by closing the gap (the difference), and on male terms, Luce Irigaray posed the question: "Equal to whom?"4 . Between man and woman there was just "pure difference." ${ }^{\text {"5 }}$

Is equality at odds with order? For Christianity, not so. All of its good news about equality-“neither Jew nor Greek, slave nor free, man nor woman"-stands together with order, and not only on the margins, but at key points: In its anthropology, Christology, Ecclesiology, and Trinitarian theology, right where the category of "headship" appears. "[T] he head of every man is Christ, the head of a woman is her husband, and the head of Christ is God" (I Cor. 11: 3). "Christ is the head of the Church, his body" (Eph. 5: 23). ${ }^{6}$ The same order can be found between the ministerial priesthood (which exercises its office in persona Christi capitis) and the common priesthood. ${ }^{7}$ It is also found between the bishop of Rome and the members of the college of bishops. ${ }^{8}$ We note that in neither of these cases is there a difference "in degree" in what is possessed. Yet, no matter this qualification, a lynchpin of Trinitarian orthodoxy, headship is considered one of the most embarrassing of Biblical notions-inspiring no end of discussion, ${ }^{9}$ if not outright dismissal. ${ }^{10}$ Headship, so it seems, necessarily subordinates the "body." This is the view of key critics of Hans Urs Balthasar who was unrelenting

\footnotetext{
(De Beauvoir 2011, pp. 159-60).

(De Beauvoir 2011, pp. 163-67).

(De Beauvoir 2011, pp. 160-61).

(Irigaray 1986, pp. 420-30).
}

5 The notion of "essential difference" or "pure difference" (taken from Derrida) is proposed by "difference feminists" such as Luce Irigaray, Jane Gallop, Hélène Cixous, and Naomi Schor. For a discussion of them, see (Grosz 1995, pp. 45-57).

6 All biblical texts shall be taken from the Revised Standard Version.

7 (John Paul II 1964, Lumen Gentium, 10, 28; John Paul II 1992, Catechism of the Catholic Church, 87, 1348, 1548). For a discussion of the relevance of the terms "in persona Christi capitis," underlying the distinction between the two priesthoods which differ "essentially and not only in degree," see (Butler 1996, pp. 290-306).

8 Lumen Gentium 22; "Explanatory Note," Lumen Gentium, 1-4.

9 Amongst Evangelicals there is a debate between "complementarians" and "egalitarians" which is chiefly concerned about the question about the ministry of women in the Church. "Egalitarians," generally want to play down the difference of "roles" in the household and deny them altogether in the ecclesial context. See (Cervin 2016). "Complementarians," on the other hand, hold out for an all-male ministry in the Church. Some, like N.T. Wright, want to hold on to the natural differences of and reciprocity between man and woman, because of the headship texts—so is "complementarian" — but does not want to apply this to the ecclesial context-so is "egalitarian." Cf. (Wright 2004a).

10 Elizabeth Schüssler-Fiorenza's "feminist critical method" takes it for granted that patriarchalizing elements in the New Testament, most notably those coming from St. Paul, are evidence of the attempt to adapt, thus corrupt, the egalitarian message of Jesus. Ironically, the latter, to her surprise, gets through untouched. "[S]ince the Gospels were written at a time when other N.T. authors clearly were attempting to adapt the role of women within the Christian community to that of 
in his insistence of the "persistent priority" of the man (ingredient in the notion of "headship"). ${ }^{11}$ Order, say his critics, is necessarily incompatible with equality. ${ }^{12}$ Then too, someone who comes from another cannot be genuinely oneself, because he or she must in some way or another be reduced to the individual needs of the "prior."13 Indeed, John Paul II himself appeared to agree with this identification of order with inequality when he chose to take the "Adam" of Genesis 2 as the "collective concept of the human species," instead of a male human being. ${ }^{14}$ When, later he emphasized the "mutual submission" of spouses in his commentary on Ephesians $5,{ }^{15}$ was he not putting the last nail in the coffin of any remaining vestiges of an order? Of course not. Neither would her, nor could he have done so. ${ }^{16}$

In what follows, I claim that headship is not only not an affront to equality, but the very condition of it where it applies to subjects who belong to each other in a relation of reciprocal and fruitful unity and distinction. Headship guarantees that equality because it establishes a unity between two who have the same thing, not abstractly, but by virtue of, and in view of, each other. It establishes an "original unity" at the origin of their being (the reason for their eventual "one flesh" union in distinctness). ${ }^{17}$ "[W]oman is not independent of man nor man of woman; for as woman was made from man, so man is now born of woman, and all things are from God" (I Cor. 11: 11-12-emphasis added). Secondly, headship guarantees the equality of subjects in their distinctness, because it is a principle of generosity. As it communicates the same identical (equal) nature, the head gives rise to another, with its own subsistence, and unique and exclusive manner of subsisting, irreducible, that is, to that of the head. The Son is not the Father, The Church is not Christ, the woman is not the man, the body is not the head. Because this principle of generosity stands at the origin of their unity, the union between the subjects never tends towards the overcoming of the difference (back to an "original" state), the one blending into the other ("modally," as it were), the second reduced back to the first. Headship, moreover, implies

patriarchal society and religion, it is all the more remarkable that not one story or statement is transmitted in which Jesus demands the cultural patriarchal adaption and submission of women" (Schüssler-Fiorenza 1994, p. 52).

11 (Balthasar 1992, pp. 283-360, especially, pp. 286-90).

12 See especially, (Beattie 1998; Crammer 2004, pp. 93-112; Gonzalez 2004; Moss and Gardner 1998; Loughlin 1999, p. 153). Elizabeth Johnson also appears to assume this view when she suggests a relation from, in the Trinity would amount to subordinationism in (Johnson 1992, pp. 216, 219).

13 Corinne Crammer, for example, writes: "If Woman comes from Man is there really a Woman, or is she simply a Male in disguise or, even worse, nonexistent? Or made up of discarded or disavowed parts of Man? ... . [I]f Woman comes froth from Man, far from being affirmed, genuine sexual difference is eradicated-the masculine is all there is, and there cannot be a polarity" (Crammer 2004, "One sex or two?", p. 103).

14 We note that this decision is tied to John Paul II's interest in showing the ontological priority of the vertical relation to God ("Original Solitude") prior to the horizontal relation between man and woman. (John Paul II 2006, p. 158, n. 12). Deborah Savage, though, presents a convincing case that the hâ'adam of Genesis 2 is not the collective 'adam of Genesis 1: "[W] hen the definitive article is used, it is a reference to a specific "human being," and, in this case, according to the narrative that follows, one who is male. And indeed, the narrative goes on to reveal that it is from the man's (hấadam) rib that the woman ('išš $\bar{a})$ is created. It seems clear from the passage that the reference is to the male at the level of the species. That is, the concrete person of the hâ'adam, while a specific individual, is at the same time representative and as it were 'contains' the whole of humanity, an interpretation that is very much in accord with Semitic thinking. That is why háa $\hat{a}^{\prime}$ remains unnamed for the most part of the narrative. However, it is essential to affirm as well that John Paul is absolutely correct to point out that it is only with the creation of 'išša (the concretely existing woman we have come to refer to as Eve) that ' $\hat{\imath} \check{s}$ (the concretely existing man we have come to refer to as Adam) appears. There is no ' $̂ \grave{s}$ without 'iššă. Some scripture scholars want to argue that Genesis 2 must be interpreted in light of Genesis 1's reference to adam and that woman and man are created simultaneously from adam in both accounts. Along with Brevard Childs, I dispute this interpretation. The Hebrew text is clear and direct in this instance. Gen 2: 22-23 states that the matter from which the woman ('išša $\bar{a})$ is formed is from the hâ' $\hat{a}^{\prime} a m$ and that the woman ('iššā) was taken out of the 'î̌s. See (Childs 1985, pp. 189-94). A careful reading of both the text and the narrative reveals the clear meaning of Genesis 2. See (Savage 2020, chp. 3, n. 37).

15 In Mulieris Dignitatem, John Paul II (1988a) interpreted the "household code" of Ephesians 5: 22-33 from the perspective of the verse just preceding it: "Be subject to one another out of reverence for Christ" (v.21), concluding that "in the relationship between husband and wife the 'subjection' is not one-sided but mutual" $(M D, 24)$.

16 John Paul II's meditates on the notions of the "head" and "body" in Ephesians 5 in (John Paul II 2006, pp. 475-87, esp. p. 480).

17 "Original Unity" is the term John Paul II uses to describe the homogeneous human nature of both the man and the woman based on the woman's coming to be from the rib of Adam, and his own coming to be as 'î̌ vis-à-vis 'iššā-the woman. It is encapsulated in Adam's affirmation: "flesh from my flesh and bone from my bones" (Gen 2: 23). See John Paul II (2006), pp. 156-62. Balthasar also notes the uniqueness of this "original unity" in creation of man, vis-à-vis that of the animals: "God not only created [man and woman] to be one in the duality of sex; he also created their duality out of their own oneness" (Balthasar 1983, p. 227). See also Aquinas, ST I, 92, 2. 
mutual reciprocity and in the most radical sense. Not only is it the case that the "second" owes itself to the head, but it is equally the case for the head who is never at any time, be it in the temporal, ontological, or logical sense, solitary and absolute, not always already determined by the one to whom the head gives rise. With headship, the whole order is included in nuce, at the very beginning, in such a way that the "second" is never just "secondary" (an "afterthought") or "second best," ultimately to be overcome. Nor, the same reason, is the "first," "in control," to make use of the "second" for his individual purposes and needs. He finds himself already in relation to the second. Both are "subject to one another" (Eph. 5: 21), therefore. Finally, it is because of the exclusive, irreducible, and coordinated (ordered) distinctness of the equal and united subjects that they are apt for fruitfulness. "Equals" who are either not thus differentiated or else differentiated but not coordinated cannot bear fruit together. The two, after all, are to become one principle of fruitfulness, together, that is, in a unity that includes their abiding difference. However, if they are not coordinated, they remain disjoined, and there is no togetherness. Similarly, if they are not significantly different, they cannot remain two while becoming one-and so that way, too, cannot bear fruit together. Sexless equality is fruitless equality as Chesterton said wryly: "When all are sexless there will be equality. There will be no women and no men. There will be but a fraternity, free and equal. The only consoling though is that it will endure but for one generation."18

The account of equality underlying this account of unity in distinction stands right at the heart of the novelty of Christian revelation. Hitherto, equality had been the contrary of the "greater and the lesser" and was achieved by evening out the differences, assumed to be unequal. ${ }^{19}$ It was precisely this mutual exclusion, of the equal and the different, that the Christian Revelation of God challenged (and orthodoxy championed); for there, there is an Origin without origin (fons totius divinitatis) who both communicates the same divinity to the second Person, and is always already determined by the Son and the Spirit precisely in His being fons ("first"). The term "Father" is not only the first Person's title, modifying an already existing subject, but his proper name. ${ }^{20}$ He is Father. Thus, as Athanasius argued, He is always already determined by the Son and the Spirit. ${ }^{21}$ To show the coincidence of order and equality, some of the early Fathers even headed unashamedly right towards the stumbling block in order to show the equality of the Son. Citing Christ's own words "the Father is greater than I," (John 14: 28) Hilary of Poitiers commented: "the Father ... . is greater because He is Father: But the Son, because He is Son, is not less."22 Indeed, this was immediately obvious to the Jews who understood that by calling God "Father," Jesus was "making himself equal with God" (John 5: 18). In light of the

18 (Chesterton 1990, p. 101). On this equality, Hans Urs Balthasar also writes: “'Equality' of the sexes prevents the real interlocking of man and woman and levels out the organic and constructive unity to one that is abstract (the identity of human nature) and ineffectual (Balthasar 1968, pp. 313-14).

19 See (Aristotle 1999, Metaphysics, Bk. X, 5). The ancient coincidence of equality with sameness is the basic assumption of modern thinking about equality. David L. Schindler notes: "The modern "enlightened" idea of unity and distinctness ... . precludes a priori any unity between $\mathrm{x}$ and $\mathrm{y}$ that is inclusive, precisely qua unity, of real difference between $\mathrm{x}$ and $\mathrm{y}$, and hence of any asymmetry in the mutual relation of $x$ and $y$. And it precludes any difference between $x$ and $y$ that is inclusive, precisely qua difference, of any real unity hence equality between $\mathrm{x}$ and $\mathrm{y}$. In a word: insofar as $\mathrm{x}$ and $\mathrm{y}$ are equal, they are necessarily the same; and insofar as they are different, they are necessarily unequal, lacking the unity that would render them equal" (Schindler 2008, p. 412).

20 See (Hook and Kimel 1995, p. 215).

21 Athanasius, Against the Arians, I, 18-19. Hans Urs Balthasar accounts for the Father's always already being determined by the Son in terms of the "active actio" ("letting go") of the Father being conditioned by the equally eternal and essential "active passio" of the Son's "letting be." See (Balthasar 1998, pp. 85-86).

22 The full text is: "The Father, who glorifies the Son, is greater: The Son, who is glorified in the Father, is not less. How can He be less, when He is in the glory of God the Father? And how can the Father not be greater? The Father therefore is greater, because He is Father: but the Son, because He is Son, is not less. By the birth of the Son the Father is constituted greater: the nature that is His by birth, does not suffer the Son to be less. The Father is greater, for the Son prays Him to render glory to manhood He has assumed. The Son is not less, for He receives back His glory with the Father. Thus, are consummated at once the mystery of the Birth, and the dispensation of the Incarnation. The Father, as Father, and as glorifying Him Who now is Son of Man, is greater: Father and Son are one, in that the Son, born of the Father, after assuming an earthly body is taken back to the glory of the Father." De Trinitate IX, 56 (SC 443). Gregory of Nazianzus also takes up Christ's words, saying that the Father is "greater [than the Son and Spirit] by the nature of causality" by which he means the generation of the Son, but then immediately adds that the Father isn't therefore greater by nature. See, Oration 29, 15 . Aquinas eventually forges 
coincidence in Christianity between order and equality, might not the logic assumed by those who see "subordinationism" behind ever order be itself subordinationistic?

There is no need to dispute the many instances in the Christian tradition that failed to acknowledge the full equality of man and woman as such — especially when it conceived the very one on whom the propagation of humanity depended, as a "misbegotten male." 23 The fact that much of the thought on the positivity of the feminine has been carried out only recently, is a case in point. ${ }^{24}$ However, none of that negates the fact that Christian Revelation from the beginning sowed the seeds for that development of thought, beginning with the Annunciation. Now, that "equality" risks utter homogenization to the point of eliminating the encounter between the sexes all together, ${ }^{25}$ it is worth turning toward "humanity's last bulwark of genuine appreciation of the difference between the sexes," as Balthasar put it, where equality and order coincide.

In the dogma of the Trinity, the Persons must be equal in dignity in order to safeguard the distinction that makes the triune God subsistent love; in a similar way the Church stresses the equal dignity of man and woman, so that the extreme oppositeness of their functions may guarantee the spiritual and physical fruitfulness of human nature. Every encroachment of one sex into the role of the other narrows the range and dynamics of humanly possible love, even when this range transcends the sphere of sexuality, birth and death and achieves the level of the virginal relationship between Christ and his Church. ${ }^{26}$

Assuming the orthodox coincidence between order and equality, we turn now unflinchingly to one of the major sources of "embarrassment" for Christianity, its category of headship on the assumption that it offers to men and women a more satisfying equality, not one between mutually indifferent, interchangeable, and sterile subjects, but between two in an original (good) and fruitful unity in distinctness, one which bears the distinction between God and the "good creation" and, behind that, the Unity in distinction of God himself.

\section{Part I: The Texts}

Let us turn first to the term "head" ( $\kappa \varepsilon \varphi \alpha \lambda \eta)$ in Scripture, where it has a specifically theological significance. There are seven such texts: Ephesians 1: 22f, 4: 15f, 5: 23; Colossians 1: 18, 2: 10, 2: 19, and I Corinthians 11: 3 . To these could be added Ephesians 1: 10, which uses a distinctive term at the root of which is $\kappa \varepsilon \varphi \alpha \lambda \eta$. It is $\alpha \vee \alpha \kappa \varepsilon \varphi \alpha \lambda \alpha$ lóo $\mu \alpha \mathrm{l}$, translated as "unite all things in Him," meaning "to sum up." In these texts, there are three subjects of headship, all of which are named in the I Corinthians text: "[T]he head of every man is Christ, the head of a woman is her husband, and the head of Christ is God." That text is the only reference to the Father as Head (of the Son). ${ }^{27}$ Every one of these texts refer to Christ. His headship is exercised with respect to two distinct points of reference. On the one hand, He is "head over all things" (Eph. 1: 22), "of all rule and authority" (Colossians 2: 10), and "of every man" (I Cor. 11: 3). On the other hand, He is "Head" of a "body," the Church (Eph. 1: 22; 4: 15f; 5: 23; Col. 1: 18; 2: 19). Finally, in two of these texts, the husband is said to be "head" of his wife who is his "body" (I Cor. 11: 3; Eph. 5: 23). There is one other relevant text where there is no explicit reference to the headship, but which resorts to the same argument as arguments for headship elsewhere. It is in I

the distinction between "principle" and "cause," where the first does not imply diversity of substance or temporal priority (ST, I. 33. 1).

23 Aristotle held that the male seed, when exposed to improper conditions such as a cold wind, may prevent the male form from mastering the female matter, resulting in the "misbegotten male." See Aristotle, On the Generation of Animals, IV.1-2; II. 3.

24 See especially (Allen 2016, pp. 361-88, 416-86).

25 See (Greely 2016).

26 (Balthasar 1986b, pp. 195-96).

27 In the New Testament, the word “God" ( $\theta \varepsilon$ ó $)$ refers to God the Father, with six exceptions, namely Jn 1: 18; 20: 28; I Jn 5: 20; Rm 9: 5; and Titus 2: 13. 
Timothy 2: 11-15: "I permit no woman to teach or to have authority ( $\alpha \dot{v} \theta \varepsilon v \tau \varepsilon \iota v)$ over men; she is to keep silent. For Adam was formed first, then Eve."

What is this headship, in the context of these texts? In the first place, the very term itself evokes the image of the source of a stream, or the top of the body, which in the ancient mind performed much the same function as the source of a stream in so far as it was understood to "send down life into the whole of the body," "nourishing" it and "growing it" (Col. 2: 19; Eph. 4: 16). ${ }^{28}$ A head is a beginning point, which bestows itself, thus a source that grounds the being and continuing growth of that of which it is head..$^{29}$ (The term $\alpha \rho x \eta$ could have been used. ${ }^{30}$ ) In the I Corinthians text, the opposite of the head is an image or reflection: "the man is the image and glory of God; but woman is the glory of man." However, an "image," of course, is not just something that looks like something else. It is image because it refers back to an origin. ${ }^{31}$ So too, "glory," which is the "fullness" of what has been received. ${ }^{32}$ This meaning of source is clear by the argument provided: "woman [was made] from the man" (I Cor. 11: 8). One can assume that the Father is Head of Christ, because Christ is His "image," as one who has come from the Father. ${ }^{33}$ This meaning of "source" or "ground" is also clear in the Colossians text where Christ is Head of "all things" because in him "all things were created." and "Head of the body" because in him "the whole fulness of deity dwells bodily" (Col. 1: 15-18).

Christ, the Head, grounds in two distinct ways with respect to the two distinct terms. In the first place, He grounds the being of the world as such: "All things were created through him and for him. He is before all things, and in him all things hold together" (Col. 1: 16-17). In the second place, He grounds the being of the Church at a level of a much greater intimacy. ${ }^{34}$ The Church, which alone is called His "body," is that place in the world that has now received "fullness of life in [Christ]" (Col. 2: 10) in whom "the whole fullness of God dwells bodily" (Col. 1: 19; 2: 9) so much so that it is the "fullness of [Christ]" (Eph. 1: 23). ${ }^{35}$ The two terms of Christ's headship are not, however, juxtaposed one next to the other. What Christ brings to life when He brings to life the Church is a humanity that was once dead (Col. 2: 12). The Church was "sanctified and cleansed," "without spot or wrinkle," by the Head, through baptism, which is precisely where one is raised from the dead (Ephesians 5: 26). Even more, though, Christ's grounding of the Church is the raison d'être of the first grounding. Christ is "head over all things for the Church" (Eph. 1: 22). Members of His body, chosen "before the foundation of the world ... to be [God's] sons through Jesus Christ," are the locus of the "plan for the fullness of time," to "unite all things in Him, things in heaven and earth" (Ephesians 1: 3-10). The body is the "fullness of him who fills all in all" (Eph. 1: 23). Concerning the interrelation between the two terms of Christ's headship, the renowned biblical scholar H. Schlier writes: "In the Church as the body of Christ the hidden wisdom of God in creation is disclosed. In His body, which represents the pleroma, the heavenly sphere of His presence, Christ draws all things into the pleroma." 36 This intrinsic link between the Church and the world vis a vis the head, is surely also intimated by the distinctive term $\alpha v \alpha \kappa \varepsilon \varphi \alpha \lambda \alpha$ เóo $\mu \alpha$ ( "to unite all things in Him") in Ephesians 1: $10 .^{37}$

28 I refer to the most authoritative commentary on the notion, the entry on $\kappa \varepsilon \varphi \alpha \lambda \eta$ by (Schlier 1965, pp. 673-82; Cerfaux 1959, pp. 331, 334). See also (Wright 2004b, p. 141).

29 Schlier, "кย $\varphi \alpha \lambda \eta$," in TDNT, 681.

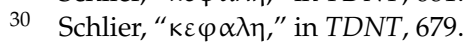

31 Schlier, " $\kappa \varepsilon \varphi \alpha \lambda \eta$," in TDNT, 679. See Aquinas on the relation between the notion of "image" and a relation of origin. ST, I, 35,1 . There he quotes Augustine who said: "One egg is not the image of another, because it is not derived from it."

32 (Balthasar 1992, p. 285). On the puzzling association of man with "image and glory" and woman with "glory" (alone) in I Corinthians 11: 7, Balthasar suggests the interplay between the immediacy of both to God, both being images (as per Genesis 1) and that of the natural horizontal relation between man and woman (as per Genesis 2). See (Balthasar 1989, p. 479).

33 Schlier, "кE $\varphi \alpha \lambda \eta$," in TDNT, 679.

34 This is the reason $\alpha \rho \chi \eta$ was likely not chose according to Schlier (" $\kappa \varepsilon \varphi \alpha \lambda \eta$," in TDNT, 679).

35 For Aquinas, the distinction is that between the potential union with Christ in grace, and actual union with Christ in grace. See ST, III, 8, 3 .

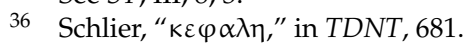

37 Schlier, "кE $\varphi \alpha \lambda \eta$," in TDNT, 681. 
Secondly, between the head and what it grounds is a common nature. God the Father is Head of Christ; but He is not the head of "every man," as in the Gnostic myth (where the "aeon" is the head of the fallen, scattered and headless body-cosmos). ${ }^{38}$ Nor is God the head of the Church; Christ is. Naturally, Christ as God does not have the same nature as "every man," but his headship of "every man" is based upon his being the "the first-born of creation," the Logos to be incarnate, the visible "image of the invisible God." He is the head of "all rule and authority" as the one in whom "the whole fulness of deity dwells bodily" (Col. 2: 9). ${ }^{39}$ That headship, moreover, is fully actualized when he has communicated His divine humanity, his "fullness," to his body, who shares in it, and now is "His fullness" (Ephesians 1: 23). ${ }^{40}$

As a caveat, we could note here that in the theological tradition, the use of the term "head" for the priesthood is found where there is something in common, as for example between the "ministerial priesthood" (exercised in persona Christi capitis) and the "common priesthood," each of which share in the one priesthood of Christ, ${ }^{41}$ then between the head of the college of bishops and its "members," each of whom possess the fullness of the sacrament of holy orders as bishops. ${ }^{42}$ Husband and wife, of course, both possess the same nature human nature to the same degree. We can speak then of equality in the sense of the "degree" of divinity or humanity, or priesthood, or holy orders, ${ }^{43}$ except of course when the headship concerns the "vertical" relation between Christ and man, or Christ and the Church where the distinction between divinity and humanity is concerned. ${ }^{44}$ Still, even there, headship is based on the sharing of a common nature.

Thirdly, headship is a generous source. This is immediately obvious in the fact that the head is always head of someone other not identical to the head, however closely identified with it. There are no bodiless heads in the Christian tradition. God, the Father is Head of the Son, who is a distinct subsistence. Then too, the creation of the world in the Son, Image of the Head, is utterly generous, in no way a mere function of God's need, nor a fallen emanation from Him. It is wholly other. Finally, when the Incarnate Son brings forth the body with which He is so intimately identified, it too is other. In the evolution of the idea of the Church as body, Christians first appear to be one somatic body; but like a somatic body they are described as "many members" of the body of Christ, and "one of another," with different functions. ${ }^{45}$ The body is a "corporate person," a "social body," made up of

38 Schlier, "кE $\varphi \alpha \lambda \eta$," in TDNT, 677.

39 When Aquinas turns to the discussion of Christ's headship over the angels, he has to face the objection of the lack of a common nature. It is because there is a common nature at least at the general level (not specific), both having rational souls, that Christ can be considered Head of the angels. See ST, III, 8, 4. Then too, when faced with the damned, Aquinas holds that because they cease to be potentially united to Christ (the Head) by grace as they once were, they cease to be members of Christ (the Head). See ST, III, 8. 3.

40 According to Aquinas, the "capital grace" bestowed on the Church by Christ is the very habitual grace received by the soul of Christ. See ST, III, 8,5 .

41 Lumen Gentium, 10. We note here that the argument in favor of an all-male "ministerial priesthood," would not be that of St. Thomas, based on the association between not being in a "state of subjection" and "eminence of degree" (ST, Supplement $39,1)$.

42 Lumen Gentium, 21.

43 In the "Explanatory Note," of Lumen Gentium it is said that between the Head of the members of the episcopal college, there is not equality (n. 1). Here though, the object of inequality are the powers, namely the exercise of the three munera (sanctifying, teaching, ruling) conferred on all bishops at consecration. At the level of exercise (powers), the Pope, as head, performs certain actions that members of the college cannot, such as the "convocation and direction of the college, approval of the norms of its activity, and so on" as well as exercising his power at any time unhindered ("Explanatory note," Lumen Gentium, 3; Lumen Gentium, 22). The head and the "members" of the college, however, have the same "fullness of the sacrament of Orders," though they exercise them in distinct ways. This is entirely in keeping with our idea of equality where the same thing is possessed in distinct and non-interchangeable manners.

44 Aquinas argues that the personal habitual grace that Christ has is greater in degree than the "capital grace" He bestows on the "body" because of the nearness of His soul to the cause of grace, His soul being more closely united to God. See ST, III, 7.9; 8.5. This, of course, is owing to the hypostatic union.

45 Romans 12: 4-5: "[A]s in one body we have many members, and all the members do not have the same function, so we, though many, are one body in Christ, and individually members of one another." I Corinthians 12: 12: "[J]ust as the body is one and has many members, and all the members of the body, though many, are one body, so it is with Christ." 
many. ${ }^{46}$ For its part, the one and diversified body is what it is by virtue of its connection with another body, the actual physical body of Christ with which the "one Bread" is identified. ${ }^{47}$ For that reason they must not become "members of a prostitute," "one body" or "one flesh" with her (I Corinthians 6: 14-16). Nor must they partake in ritual food offered to demons; for they together ("though many") are "one body" partaking in the "one bread," the body and blood of Christ (I Corinthians 10: 14-21). Later, in the captivity epistles, where the notion of the Church as body plays a critical role, Christ is the "Head" of that body. At first, it appears as though the body were quasi una persona with the Head who fills it with "fullness," in the way the head of an organic body sends down life into the whole of the body (Colossians 2: 9-10; Ephesians, 1: 3-23). ${ }^{48}$ However, then that same body appears to be a "bride," personally distinct from the head. What appear to be two alternatives, are instead inter-connected; for the very "presentation" of the Church-Bride to the Bridegroom depends upon her first being "grounded" by Him. She is first "sanctified" and "cleansed" by the "washing of the water and the word" (Ephesians 5: 26), a likely reference to baptism, so that "he might present the church to himself in splendor, without spot or wrinkle or any such thing, that she might be holy and without blemish." 49 This order of things is clearly in mind when St. Paul turns to the domestic image of the relation between Christ and the Church. Both Pauline references to the wife as "body" refer back to the primal account of what preceded the "presentation" of the woman to man. I Corinthians 11: 8 does so explicitly: "Woman [was made] from man." Ephesians 5 is less explicit, but the allusion is clear when St. Paul quotes Genesis 2: 24: "For this reason a man shall leave his father and mother and be joined to his wife, and the two shall become one flesh" (5: 31). For what reason? He is referring to the previous verse in Genesis 23: "This is at last bone of my bones and flesh of my flesh; she shall be called Woman, because she was taken out of Man." In sum, the source generated another, that is irreducibly distinct.

Fourthly, the head is always already determined by the one of which it is a ground. The Father is always Father of the Son. Christ as the "First-born of creation," is always the First-born of "all men." This is especially clear when the head is head of a body. As John Paul II said, commenting on Ephesians 5 , "the body has life from the head (even if at the same time, although in a different way, the head has life from the body." ${ }^{50}$ Just as hâ'adam in Genesis 2 is always already expecting the woman, the head is always already expecting the body. It was never good to be alone. ${ }^{51}$

Our inquiry takes up the charge that order and equality are incompatible bedfellows. By looking at the elemental characteristics of headship, as they appear in the Biblical texts, we have begun to see not only that they are compatible, but that they are necessary to each other if the "fellows" are not to be merely standing next to each other on a "spectrum," but rather turned toward each other, already belonging to each other, and generously so, in an insurmountable (and fruitful) unity in distinction.

Let us now ask more deeply the content of headship. What is it about? In the biblical texts, headship is invoked in the context of some sort of disorder either in the household (Ephesians 5) or in the Assembly, (I Tim. 2: 12; I Cor. 11: 6). The issues appear to concern practical matters (lack of love from husbands, respect from wives, women teaching in the assembly, and appearing without a "sign of authority" or veils). ${ }^{52}$ Some of the particulars could perhaps be dismissed as culturally bound (as for example the particular sign of a woman's married state). However, the argument invoked to deal with them, of course, is not. The whole order of the cosmos is brought to bear on them. In view of this,

46 For a discussion of the idea of the "corporate personality," see (Atkinson 2014, pp. 161-92).

47 See the discussion of the identification of this collective "body" with the actual physical body of Christ with which the "bread" of the Eucharist is identified (I Corinthians 10: 14-21) in (Cerfaux 1959, pp. 274-77).

48 (Cerfaux 1959, pp. 331-34)

49 See (John Paul II 2006, p. 482).

50 (John Paul II 2006, p. 479).

51 Commenting on the first man in Genesis 2, Balthasar writes: “[The fact that Adam's loneliness is 'not good,'] ... . Banishes the idea of a primal, androgynous human being, supposedly originally at peace with himself and only subject to unsatisfied longing after being split into two sexes" (Balthasar 1990, p. 373).

52 See note 117 below. 
I suggest that the "practical matters," might themselves be about something much bigger, and that what they are about, far from being a vestigial remnant of the Apostle's cultural boundedness, is the novelty of Christianity coming up against the culture of the time. In this case, headship would reveal something new, and for both the body and the head. We will consider this possibility in that order.

\section{Part II: "Mater est Certa": Acknowledging the Father}

Before Telemachos goes off in search of his father, Odysseus, he gives voice to a universal uncertainty: "My mother says I am his. I for my part do not know. Nobody really knows his own father." ${ }^{53}$ Mater est certa; and only she knows for certain who the father is. It is not difficult to understand why this is so. The child is physically attached to the mother, but physically detached from the father, from the very beginning when his reproductive cell detaches totally from his body and joins to the reproductive cell in the mother's body. From the very beginning, the child is outside the father. When, then, the child is born, he is also at a significant temporal remove from his father, by nine months. To make the point bluntly, the father can be dead and buried when the child is born. ${ }^{54}$ Indeed, so invisible is the reproductive role of the father, there is not only the question of who one's father is, but whether one has one at all. ${ }^{55}$ Some ancient cultures, even cultures as recent as the 20th century, appear to have been unclear that the male had any role at all, suggesting that children were generated parthenogenetically, as it were, as in some species at the lower end of animal life. ${ }^{56}$ These cultures were, predictably, also matrilineal, where the line was channeled through female descent (though governed by the mother's brother according to the Avunculate)..$^{57}$

There is a theological correlate to this "uncertainty" about the father. ${ }^{58}$ It is the ancient certainty about the "Great Mother." In Hesiod's cosmogony after Gaia emerges out of the pre-existing chaos, she gives birth to the mountains and the sea "without mating in sweet love" with her consort Ouranos (Heaven) to whom she had given birth before. ${ }^{59}$ Together they then have many children, the most important of whom was Chronos, father of Zeus. However, Gaia is the mother of the life in the (almost) radical sense, being first the mother of her own husband. There were many variations on "Gaia" in the ancient world, especially in Asia Minor: the "Great Mother," the "Mountain Mother," "Ma," "Bellona," Cybele," "Demeter." 60 The fertility goddess "Artemis" with the many breasts (or testicles) hanging from her midriff is the one that is most relevant for the backdrop of early Christianity. She is the reason for a riot of silversmiths in Ephesus where there was the largest temple built for her. With their livelihood in jeopardy thanks especially St. Paul, who enjoined its followers to shun idolatry, they cried for two hours: "Great is Artemis of the Ephesians!" (Acts 19: 23-28). Artemis, as it happens, was served either by female priestesses or male priests, "deprived of their power" (through ritual castration). ${ }^{61}$

It is not difficult to ascertain the central theological feature of the cult of the Great Mother. It is decidedly immanentistic, in the sense that the world "grows out of," and is identified with, her.

53 (Lattimore 2007, I, p. 215).

54 Jose Granados writes: "[R]egarding time, the relationship of the father with the child takes place in the future; regarding space, it happens outside of him" (Granados 2009, p. 188). See also (Ong 1981, Fighting for Life, p. 175).

55 Plutarch spoke critically of those who considered the female seed "a power of origin," (Moralia, 374F). The Anthropologist Bronislaw Malinowski describes the Melanesian Trobrianders who thought the woman bears children of herself (once her womb is opened) through the implantation and reincarnation of departed spirits. Children, accordingly, do not think of their fathers as their fathers, calling them "husband of my mother." See (Malinowski 1927, p. 12). See also (Miller 1999, Calling God 'Father,' pp. 11-17).

56 For a fascinating discussion of male consciousness against the backdrop of the "expendability," even complete absence, of the male along the ladder of animal life, see (Ong 1981, pp. 52-56).

57 (Millet 1969, p. 25, n. 4; p. 28).

58 There is some link between matrilineal, or "matrifocal" cultures, and the religion of the "Great Mother," above all, in Asia Minor. Cf. (Ramsay 1895, p. 95).

59 (Hesiod 1983, 18, line 154).

60 (Kroeger and Kroeger 1992, pp. 50-53, 105-10).

61 (Kroeger and Kroeger 1992, pp. 94, 164). 
Goddess feminists themselves confirm this when they jettison the "dualistic" distinction between God and the world, and adopt in its stead a "unitary conception," of "that which surrounds another," the world being "God's body." ${ }^{62}$ Modern goddess feminists also know that the choice for this "unitary conception" is not a choice for something as peaceful as many imagine goddess religion to be. ${ }^{63}$ Rather, they acknowledge it is a choice for a world of pure becoming, of getting used to the contradiction between life and death as part of the "cycle of life." ${ }^{\prime 4}$ The resignation is consistent with the first principles of a life conceived as owing itself solely to, and fundamentally identical with, the Great Mother who is all-encompassing, and exercises total control over her "children," they being essentially hers. She is possessive, consuming, smothering and enveloping to the point of death. ${ }^{65}$ She is a "barbaric and formidable deity who embodies the ruthless fecundity of nature, and [whose] rites are usually marked by licentiousness and cruelty." 66 That this is not some mythical fantasy of the past, we need only consider the many distorted forms of maternal possession of children, immortalized in literature. ${ }^{67}$ Worse, we need only think of the almost universal right given to mothers to decide whether or not to allow an unborn child to live or have it killed. As Walter Ong said: "More total power over another is unthinkable." ${ }^{\prime 68}$

A final comment should be made about this account. Fathers are "in the picture," but not happily so. They are usually at enmity with their sons who, should they escape their fathers' deadly plots, work in league with their mothers, almost oedipally, to usurp them. The castration of the first father, Ouranos, by Chronos, is a powerful symbol of this toxic combination of paternal power and envy and maternal deception and circumvention of the father's power to beget. ${ }^{69}$ It is a vicious circle; but one which began with the Mother who brought forth the world "without mating in sweet love," beginning with her own husband (her son). Some have suggested that the most glaring misogynistic statements, especially the downgrading of the female part in reproduction, are themselves overreactions to and defense against the totalizing claims and power of the Great Mother. ${ }^{70}$ The famous speech of Apollo, in the Oresteia would be emblematic of this. Speaking for the protagonist, Orestes, who has killed his mother to avenge the death of his father, Apollo turns to Athena who was "never fostered in the dark of the womb" and is "for the male," and says: "The mother is no parent of that which is called her child, but only nurse of the new-planted seed that grows. The parent is he who mounts. A stranger she preserves a stranger's seed." 71 There is, of course, the famous Aristotelian account of generation in which the woman contributes only matter, which then only results in a female if the matter thwarts the "mastering" efforts of the seed (form) from the man. ${ }^{72}$ On both of these texts are showered all kinds of vitriol from feminist circles and beyond. ${ }^{73}$ There is good reason for this; but if the above thesis is

62 Sallie McFague, Daphne Hampson and Carol Christ all propose "pan-entheism," God being the "soul" of the world "body," while also transcending it. See (McFague 1993; Hampson 1996, p. 165; Christ 2002, pp. 86, 88).

63 For an example of the thesis that cultures based on the mother goddess were utopian see (Davis 1971) and (Gimbutas 1991).

64 Carol Christ, a post-Christian feminist, for example, finds it "comforting to think of [our]bodies decaying in the earth becoming food for the renewal of other life forms" (Christ 2002, p. 89).

65 Walter Ong associates the Great Mother with the form of violence characteristic of women. "Possessiveness can be selfish and kill, and possessiveness relates particularly to woman, as in the widespread mythological symbol of the impersonal, possessive, unwittingly selfish Great Mother, whose children are for her not persons but possessions that she consumes or smothers (envelopes to the point of death)." See (Ong 1981, Fighting for Life, p. 100).

66 (Dawson 2009, p. 226).

67 C.S. Lewis makes much of the possessive mother in his literature. "Mrs. Fidget," who "lives for her family" is suffocating (Lewis 1960, pp. 53-83). And "Pam," during her visit to heaven, is furious she cannot see her son who is already there says: "No one has a right to come between me and my son. Not even God" (Lewis and Whitfield 1946, p. 95).

68 (Ong 1981, p. 70).

69 Miller speaks of the "fathering crisis" in the ancient Near East during the second millennium B.C. Speaking of mythical fathers, he says: "their marginality, cruelty, incompetence, and powerlessness, more often than not, pose dilemmas to which mother, son or daughter deities must respond either by defending themselves or by taking action to uphold the universe in their stead" (Miller 1999, p. 35).

70 (Millet 1969, p. 28; Ong 1981, p. 69).

71 (Aeschylus 1953, pp. 161, 158).

72 On the Generation of Animals, IV.1-2; II. 3.

73 (Elshtain 1981, p. 44; Keuls 1993, p. 145). 
correct, such statements are likely over-compensation for what is so manifestly the case, that mater est certa. To put it simply, the over-compensation, however unjustified and inadequate (in no uncertain terms), may be a matter of establishing some equality for the father and getting some much need light between the Mother and her oedipal "child."

There is another variant of the Great Mother, one that shows up in the cosmogonic myths of Gnosticism, another influence in the background of first century Christianity. ${ }^{74}$ One can detect it especially in references about those in Ephesus given to "godless chatter and contradictions of what is falsely called knowledge" (I Timothy 6: 20), to "godless and silly myths," (I Timothy 4: 7), those who have "strayed after Satan" (I Timothy 5: 15), and to those under the sway of men like Jannes and Jambres - the two magicians of Pharaoh who opposed Moses with their use of serpents- "men of corrupt mind and counterfeit faith" (II Timothy 3: 6-9). The difference in the Gnostic myths, however, is that the "Mother" now comes from above. This is cause for great jubilation for some who are disconcerted by the uniquely paternal character of God in Judaism, Christianity. ${ }^{75}$ What can go unnoticed, though, is that in Gnosticism, where the ultimate cause of the fall into matter comes from within the god-head, it is the maternal side of the godhead that is responsible for it. ${ }^{76}$ With variations on the same theme, ${ }^{77}$ it is the Mother who, in her lower double ("Sophia") commits the "original sin" by foolishly pulling away from her consort and having a child by herself. ${ }^{78}$ That child is Ialdabaoth, the creator of the material cosmos. Here, again, the world comes from a mother conceiving by herself. ${ }^{79}$ In this case, though, it is clearly a tragedy. Thus, when the higher double of "Sophia" becomes the vehicle of salvation-pulling back the particles of spirit that have come under the dominion of matter-it is salvation from her lower double's misstep. ${ }^{80}$

Apropos of the order between Adam and Eve, we should also note the Gnostic reversal of the Genesis account. It is Eve who pre-exists Adam, insofar as the divine Mother is in her. ${ }^{81}$ And it is Adam who is deceived, knowing nothing of the higher "aeons," only then to be enlightened by Eve under the instruction of the beneficent Serpent who offers liberation from the "jealous" Creator. ${ }^{82}$ It is difficult not to see this reversal as a possible background for the text of St. Paul addressed to Timothy at Ephesus: "Adam was formed first, then Eve; and Adam was not deceived, but the woman ... " (I Tim. 2: 13-14). In that case, what immediately precedes the reference to Genesis would have a more cosmic significance. As some have argued, the statement "I permit no woman to teach or to have authority ( $\alpha \hat{v} \theta \varepsilon v \tau \varepsilon \iota v)$ over men," may refer more to what some women influenced by Gnosticism were teaching, namely that they were the origin of men. ${ }^{83}$

74 Though Gnostic documents were written notably later than the beginning of Christianity, the existence of large Gnostic movements pre-existed Christianity affecting it from the very beginning. See (Bonsirven 1963, pp. xx-xxiv; Cerfaux 1959, pp. 270-72; Jonas 1963, p. 31; Schlier 1968, pp. 115-31).

(Pagels 1979, The Gnostic Gospels, pp. 48-69).

76 (Jonas 1963, p. 196).

77 Irenaeus refers to the "inconsistent opinions of those heretics" (Against Heresies I.11.1, in (Roberts and Donaldson 2010, p. 70)).

78 (Jonas 1963, pp. 106, 200-1). Pagels provides an account of this (Pagels 1979, p. 54).

79 Tertullian and Irenaeus both rebuke this idea when addressing Gnosticism. See Tertullian, Against the Valentinians 10; Irenaeus, Against Heresies 1.2.4.

80 Depending on the account, at the top level of "aeons," each of which consist in male-female couples (syzygies), is the Mother, called "Pronoia," "Epinoia," or "Barbelo." See Jonas's description of the account of Simon Magus and that of Valentinus (Jonas 1963, pp. 103-11, 179-97).

81 (Jonas 1963, p. 204).

82 (Jonas 1963, pp. 92-94, 204).

83 This is the central thesis of I Suffer not a Woman, by Kroeger and Kroeger. It is based on the reading of the Greek word $\alpha \tilde{v} \theta \varepsilon \vee \tau \varepsilon \iota v-$ which occurs only once in the New Testament—as "beginning" or "author," or "originator." The Kroegers also note that the word is often used extra-biblically in the violent sense of tyranny or usurpation and sometimes associated with ritual castration and murder (Kroeger and Kroeger 1992, I Suffer not a Woman, Rethinking I Timothy 2:11-15 in Light of Ancient Evidence, pp. 87-98; pp. 185-88). I am sympathetic to the Kroegers' reading, though I see no reason to draw the conclusion they do, the central aim of the book, namely, that there is no reason for a male-female distinction in ministries in the Church. N.T. Wright also considers the pagan backdrop, in his case the Great Mother (Artemis), to explain the text in Timothy. See (Wright 2006, p. 9). 
In view of a later point, we should note the ultimate reason for the generally negative conception of the material world in Gnosticism. The Mother who is ultimately responsible for it, is not a distinct personal subject, distinct from the Father, but only the "other side," or mode, of the Father. ${ }^{84}$ Indeed, she is not even unambiguously mother. ${ }^{85}$ To put it in Christian Trinitarian terms, there is no coincidence of essential unity and personal distinctness. Thus, the distinction between the Father and the Mother comes at the expense of the unity, a "pulling away"- "conceiving alone"- the fruit of which, in its turn, can only be conceived in negative terms. The implication is not that had the Mother "stayed with" her consort they would have conceived a better world, but rather, that they would have conceived no world at all! All of this accounts for why what appears on one hand to be so "female positive," can end up so female negative, as heard in Gnostic statement such as "[Christ came to earth to] destroy the works of the female." 86 The fact that the Christian account has such a positive account of the material world ought to prompt a reconsideration of the goodness of its Creator and His fatherhood ${ }^{87}$

What is it that the fatherhood of the Creator suggests? ${ }^{88}$ Let us note first that in the progressive revelation of the God of Jesus Christ, the word "Father" denotes not mere traits or attributes of God but is what God is called. It is his name. He is not, therefore, merely "father-like" (in the same way in which He might also be "mother-like"). He is "Father." ${ }^{\prime 9}$ In this sense, then, God's Fatherhood concerns the essential qualifications for being a father, those exclusive to a father (with respect to those exclusive to a mother).${ }^{90}$ Then too, divine fatherhood is not merely metaphorical, where the fatherhood predicated of God is first found in the created order, as an imperfect participation in a divine perfection, as for example when we say that God is "rock" or a "lion." With fatherhood, it is the other way around. It is found primarily in God, and as proper to Him, be it in the not-yet Trinitarian sense used in the Old Testament for the "I AM" who is the Origin of the world (Deut. 32: 6; Job 38: 28; Mal 2: 10), be it in the fully inter-personal sense used in the New Testament, for the Origin of the Son, in whom all things were created..$^{91} \mathrm{He}$ is the archetype of all creaturely fatherhood (Ephesians 3: 14). It is because God is Father that that there are fathers in the world. Indeed, it is because in God there is a Father that there is

84 See Michel. Waldstein's study on "Secret John," on which the Valentinian account is based: (Turner and McGuire 1997, pp. 164-70).

85 See (Buckley 1986, p. 41); (King 1988, pp. 158-76, esp. p. 162).

86 Clement of Alexandria, Stromata III, IX, 63, in (Oulton and Chadwick 1954, p. 69). The end of The Gospel of Thomas concludes: “Simon Peter said to him [Yeshua]: 'Let Mary leave us, for women are not worthy of Life.' Yeshua answered 'This is how I will guide her so that she becomes Man. She too will become a living breath like you Men. Any woman who makes herself a Man will enter into the Kingdom of God'" (Rowe 2005, pp. 57, 114).

87 On this point, see (Miller 1999), Calling God 'Father,' the central point of which is to show the novelty of the Fatherhood of the Jewish God against the contemporary portraits of father-gods in the myths of the ancient Near East. Miller rebuts the critics of biblical patriarchalism who assume fatherhood in the Old Testament is determined by the cultural backdrop.

88 We do not suggest here that only the first Person of the Trinity is Creator. "All things caused are the common work of the whole Godhead," as Thomas says, citing Dionysius (1897, On the Divine Names, 2). As Aquinas argues, since "every agent causes its like," and since what is caused in creation is the very being of the world, creation belongs to God according to what is common to the Divine Persons (Aquinas, ST, I, 45. 6). Nonetheless, just as the common nature belongs to the Divine Persons in a kind of order, so too do the essential attributes (omnipotence, etc.). Thus, too, in the act of creation, the virtus creandi is possessed by the Son as from the Father and by the Holy Spirit as from the Father and the Son. In this sense, then, says Aquinas, "to be the Creator is attributed to the Father as to Him Who does not receive the power of creation from another" (Aquinas, ST, I, 45. 6, resp. ad 2). Thus, we begin the Creed by saying: "I believe in God the Father Almighty, Creator of Heaven and Earth." As for the use of "Father" for Creator in the Old Testament where there is, of course, no explicit knowledge of the Trinity, we cannot exclude an implicit "suggestion" of it, as the Catechism of the Catholic Church says, citing Ps. 33: 6, 104: 30 and Gen. 1: 20-3 (cf. CCC, 292). Indeed, to the Jewish people, it is a personal divinity that is revealed, One who was in always acting to reveal himself as he is in himself, namely, as One that is never without his Only-begotten and their common Holy Spirit.

89 See Miller's discussion of the mother-like attributes associated with God in the Bible who is, however, never called "Mother" nor address as "she" (Miller 1999, pp. 45-52). See also (Hook and Kimel 1993).

90 The distinction here is that between the mutually exclusive differences between a father and a mother and the "attributes"- propensities, tendencies, traits—which belong to their common humanity, but which may be stronger in one or the other. This latter level of difference is not immaterial. Those propensities by which one or the other sex "appropriates" a common attribute, are themselves the fruit of the influence of the mutually exclusive differences on the whole of the nature, common to each. Still, those differences are on a level which makes reference to a more basic one.

91 See Aquinas, ST, I, 13. 3; I, 33.2, ad 4. 
anything at all. ${ }^{92}$ Now keeping in mind that the fatherhood that is at the origin of creation concerns the essential qualifications of fatherhood, let us note briefly four distinguishing features of fatherhood in general and with respect to creation.

In the first place, fatherhood is the outside principle in the generation of life. As Aristotle said, the male generates in another while the female generates in herself. ${ }^{93}$ With respect to the "certainty of the mother," the fatherhood of God requires "Mother Nature" to look to something outside of her to account for the life she brings forth. The world does not "give birth" by itself. Every creature, as Balthasar says, "is originally the fruit of the primary, absolute, self-giving divine love ... Parthenogenesis can have no place." ${ }^{\prime 94}$

Secondly, just as the father "comes in from the outside," the fruit of his begetting is also at a remove from him. His child is not identical to him, however much begotten by him. ${ }^{95}$ So too the world does not emerge from the Deity (be it from the Great Mother, or the Gnostic Mother in its fall into matter). It is not God. It is precisely this feature of the otherness of the creature from the Creator that the Jewish God presents Himself as Father, as Benedict XVI wrote:

The mother-deities that completely surrounded the people of Israel and the New Testament Church create a picture of the relation between God and the world that is completely opposed to the biblical image of God. These deities always, and probably inevitably, imply some form of pantheism in which the difference between Creator and creature disappears .... . By contrast, the image of the Father was and is apt for expressing the otherness of Creator and creature." 96

This non-identity of the father with his "progeny" is, of course, a principle of transcendence but not a transcendence opposed to immanence. On the contrary, the transcendence of the biblical God, becomes immanence (beginning in God Himself where the self-communication of the Father lets another be and in so doing, fills that other in the way that the Giver fills his gift). Indeed, it is the coincidence of the two that came to the fore in Israel's growing understanding of the fatherhood of God who was not only the source of the world but "involved" with it. ${ }^{97}$ This becomes most evident in the Covenant-to which creation was a preamble-where Israel becomes the "first born son of God" (Exodus 4: 22). As Roch Kereszty says:

Instead of fading away or being transformed into a lesser god, Yahweh draws nearer to his people while at the same time he 'grows in stature.' He reveals himself eventually not only as the 'god above all gods,' but the only God, the creator of all and the sole master of history. Israel simultaneously experiences his threatening holiness and loving fatherhood. He is both the Holy One of Israel and Israel's Father. The awareness of his unbearable otherness and that of his faithful and tender, fatherly and motherly love grow together. ${ }^{98}$

Thirdly, fatherhood is associated with freedom. Because the father is on the outside of the whole process of the development of the child, from conception to birth, he needs to take ownership of his fatherhood (after becoming certain of it). Fatherhood is not simply natural. So too, looking at

92 According to Aquinas, the processions of the divine Persons are the cause of creation (I, 45. 6, ad 1). More specifically, the procession of the Son from the Father is the "principle of the production of creatures." I, 33, 3, ad 1.

93 "[B]y a male we mean that which generates in another, and by a female that which generates in itself." On the Generation of Animals, I. 2.

94 (Balthasar 1992, p. 287).

95 Of course, children are also distinct from their mothers. However, because of their close identification with them, they have to undergo the process of separation from them. There is no such process with one's father. On this point, see (Ong 1981, pp. 175-76).

96 (Ratzinger 2007, p. 140).

97 See also John Miller who maintains that the "involved father" is the most distinctive difference between the Father of the Old Testament and all the other father deities belonging to contemporary ancient Near Eastern myths (Miller 1999, pp. 12-14).

98 (Kereszty 1999, "God the Father," p. 261). 
creation-but also the covenant for which creation is the preamble-creation is not natural to God, in the sense of being "automatic," necessary. Creation is a gratuitous and electing act. It is a choice to "be involved." When we think this aspect together with the previous one, of creating something other, we can see even more the depth of the gratuity at the origin of Creation. It is not just that God is free to create (or not), but that He has chosen to bring forth a world that shares in the same freedom with which He created it. The world owes itself to the gratuitous generosity of the Creator, and is at the same time a gift to itself, to be itself, with its own inner "principle of motion and rest" (to the point that for free creatures this becomes even the possibility of evil, and "risk-taking" for the Creator Himself). ${ }^{99}$ By virtue of receiving its being—esse creatum-from God, the creature is thereby the created subject of itsown existence. ${ }^{100}$ These are the two sides of the gratuity of creation, of divine Fatherly "involvement" with the world.

The fourth dimension of fatherhood pertains exclusively to God. It is the fact that for God, the gratuitousness of his creative love is an absolute beginning. There is no "partner" "collaborating" with the Creator in the sense of something presupposed, be it a material substrate "out there," be it a principle in the divine itself that is "on the side of the world" ("Sophia") existing retroactively, so to speak, to explain the actual decent into matter. On the contrary, the "partner" is God's very creature. This is the point that Balthasar always has in mind when he insists on the "persistent primacy of the man." It is that the feminine creature not only does not bring forth life alone, but that she herself is brought forth by the Creator. ${ }^{101}$ Lest this appears to be a deprecation of the feminine creature, the contrary appears to be the case, since wherever the feminine creature is a "collaborator" of the divine, be it as a principle in the divine (the Gnostic syzygia), be it in the "sacred marriage" (hieros gamos) between heaven and earth (spirit and matter), there is always the risk of devaluing the feminine side. ${ }^{102}$ Given the "good creation" created freely by God we should expect a different result for the feminine creature as well.

Once again, though, the world is not God's body, and He is not its head, since the world is not God's counterpart, nor does it have with God a common nature. Thus any "persistent priority" in the worldly realm which would reflect the fatherly Creator, has to look further back to the reasons for the Creator's absolute priority, why the world is not His body that is. Here we are faced with something counter intuitive perhaps, namely that the very reason the world is not necessary for God-a central Christian teaching ${ }^{103}$ - is the same reason it is created. If God does not need the world-be it in the sense that the divine is caught up necessarily in the inescapable duality of the infinite and the finite, be it in the sense that he needs it to actualize his possibilities, even the need to be diffusive-why does He create it? It is because in God there is already another who is thoroughly positive, equal with the "first," not that is the lesser precondition for the decent into multiplicity and matter "on the side of the world," so to speak (as with Gnosticism and Arianism). It is because there is the procession of the Son (and of the Holy Spirit) that the world is not-necessary to God. ${ }^{104}$ And yet that same reality is the causa

99 See (Schmitz 1982, The Gift: Creation, pp. 91-93).

100 See here Adrian Walker's discussion of the Thomistic formula: "esse significat aliquid completum et simplex, sed non subsistens" (Walker 2004, pp. 457-79, esp. p. 470).

101 (Balthasar 1992, pp. 287, 293, 296; 1998, p. 91; 1986b, p. 189; 1989, p. 482; 1991, p. 165). In his Mariology, Balthasar insists on the priority of the Mary as Bride before Mary as Mother (Theotokos), and thus on the asymmetrical reciprocity between the woman coming (first) from the man then the man coming (second) from the woman (as child), as indicated by I Corinthians 11: 12 ("As woman was made from man, so man is made from woman"). The point of Mary's non primacy for Balthasar, is to place the absolute source of the new creation in the Christ the Redeemer, as the absolute source for the Creation is the Creator (not the "Magna Mater"). Thus, for Mary, she is first the Immaculata, by virtue of the grace of her Son, before she is His mother. Thus, "the effect is the cause of the cause" (Balthasar 1992, pp. 288-300), or as Dante's St. Bernard addresses Mary: "Virgin Mother, daughter of your Son" (Dante 2004, Paradiso, 33, 1).

102 (Balthasar 1990, Theo-Drama, II, pp. 366-68).

103 Dei Filius, 1: DS 3002; cf. Lateran Council IV (1215): DS 800.

104 Aquinas, ST, I, 32.1, ad 3. 
et ratio of the world. ${ }^{105}$ To put it in the terms Hans Urs Balthasar used, it is because of the "positivity of the other" ad intra that God can create ad extra freely, and with a reason (not arbitrarily). In other words, it is because there is a "head" in God, from whom one always proceeds in perfect equality, that there can be a world (that proceeds from him in inequality) in the first place. Moreover, it is because that that procession is good, that the "not God" (the world) can also be in the most radical sense "very good," indeed the very expression of the communion that God is. ${ }^{106}$ It is at this point, and only at this point, that we can allow ourselves to consider the created world in feminine terms, not only because God does not need the world (a "counterpart"), but also because the world is the freely created expression of the utter positivity of the other in God. ${ }^{107}$ We can even think of the positivity of not being God. ${ }^{108}$ It is another question, for another time, to entertain, the possibility that in God Himself, in His inter-Trinitarian life, there is a feminine principle. ${ }^{109}$

What can we now say about headship in the worldly sphere? Looking at things from the side of creature, the woman, and the ecclesial body-bride (and its common priesthood), acknowledgement of the head is the acknowledgment of an outside (transcendent) source of life, a fact about which there might be some "uncertainty," given its apparent distance and invisibility, especially against the backdrop of something so manifestly real and fruitful. It is the acknowledgment of the fact of "being loved first," keeping in mind everything that has been said about the very possibility of creation to begin with. ${ }^{110}$ This concerns in the first place the woman, creature herself, who comes "from the side of man" in the bestowal of being itself ("Christ is the head over all things") and then, for the Church, as the result of Christ's "capital" grace (Christ is "head of the body"). ${ }^{111}$ The Church 'Bride,' knows that she "continually receives her being and life from the well-springs of God-made-man; they are not her own creation." 112 It is not just a matter of "entering into a relationship," but of being in one from the beginning, even more, being constituted by one. ${ }^{113}$ Acknowledgement of the head, secondarily, then, concerns the fruit she bears with the man. She is certain about the father and knows that the life

105 Aquinas argues that though the proper cause of worldly being is what is common to the Persons-the one Essence-since what is caused is being itself, "the divine Persons, according to the nature of their procession, have a causality respecting the creation of things" (ST, I, 45. 6). Continuing though, he argues: "the divine nature, although common to the three Persons, still belongs to them in a kind of order, inasmuch as the Son receives the divine nature from the Father, and the Holy Ghost from both; so also likewise the power of creation (the virtus creandi), whilst common to the three Persons, belongs to them in a kind of order. For the Son receives it from the Father, and the Holy Ghost from both $(S T, \mathrm{I}, 45,6, a d 2)$. Thus, he can say that the processions themselves are causa et ratio of creation (ST, I, 45, 7, ad 3). See also De Potentia Dei, Q. 2. 5-6 where Thomas shows that the omnipotence exercised in the creation of the world is the same omnipotence of the eternal generation of the Son as a power.

106 At the beginning of his long excursus on "the World from the Trinity," Balthasar makes the case, with A. Gerken, that "the possibility of creation rests in the reality of the Trinity. A non-trinitarian God could not be the Creator" (Theo-Drama, vol. V, 61). To make the case he reaches back to Bonaventure's axiom: "De necessitate si est productio dissimilis praeintelligitur productio similis" (Hexaem. XI, 9 [V, 381], quoted in (Balthasar 1998), Theo-Drama, vol. V, p. 65). See also (Balthasar 1933, pp. 111-19).

107 For Balthasar, it is for both of these reasons that he is unwilling to think out the relation between God and the world in sexual terms before the gratuity of creation is established. See (Balthasar 1992, pp. 287-88; 1989, pp. 472-73).

108 David C. Schindler argues for the positivity of not being God, therefore of motherhood and creatureliness (both of which owe themselves to a fatherly source), on the grounds of the positivity of the other in God. See (Schindler 2019, pp. 261-63).

109 See (Balthasar 1998, Theo-Drama, vol. V, pp. 81-91). Balthasar considers the "super-sexuality" in terms of the relational attributes on each side of the Trinitarian processions. Thus, there is an "active actio" or "letting go" (male giving) and an "active passio" or "letting be" (female receiving) that obtains for each of the Trinitarian Persons and on each side of the Trinitarian relations. However, because sexual difference is not primarily a matter of attributes within individuals, but of two coordinated and mutually exclusive and irreducible modes of possessing the same nature, I would pursue a "super-sexuality" in another way, one which links the sexual difference to what is mutually exclusive and irreducible in the Trinity, the relations themselves (and not to "attributes" possessed by each of the Persons). Cf. note 121, below. In view of that proposal I would refer to various considerations of the Holy Spirit as the principle of the feminine (or motherhood): (Ratzinger 1983, pp. 26-27; le Guillou 2009, pp. 366-67; Congar 2018, pp. 155-64; de Cortázar 2017, pp. 91-114).

110 The head does not stand for the Creator simply but for what makes creation possible for the God who does not need it.

111 The "grace" of Christ is "capital" because it is bestowed. See The Catechism of the Catholic Church, 875: "No one can bestow grace on himself; it must be given and offered.

112 (Balthasar 1992, p. 355).

113 This organic aspect of headship is particularly relevant for the relation that stands between the Roman Pontiff and the members of the college of bishops, as noted at the II Vatican Council: "[H]ierarchical communion with the head and members is required. The idea of communion was highly valued in the early Church, as indeed it is today especially in the East. It is not to be understood as some vague sort of goodwill, but as something organic" ("Explanatory Note," Lumen Gentium, 2). 
she brings forth is "with the help of the Lord" (Genesis 4: 1). ${ }^{114}$ She even marvels at the miracle of life that comes from her. Interestingly, it is precisely against the backdrop of creation, that the mother of the seven Jewish brothers exclaims: "I do not know how you came into being in my womb. It was not I who gave you life and breath, nor I who set in order the elements within each of you (II Maccabees, 7: 22). Against the dominant cultural backdrop ("mater est certa"), this is breathtaking. In this sense, the woman acknowledges the father, "letting him in" to her life, and into the life of the child. ${ }^{115}$ In this sense she is what some have called, the "eternal feminine," insofar as she unites creation with its eternal source. ${ }^{116}$

From a postlapsarian point of view, we could say that headship for the woman is a correction of her worst (sinful) tendencies, namely to think of herself as the "mother of the living," independent of the man (without her "veil"). ${ }^{117}$ (How literal this is actually becoming with artificial insemination!) As for the Church, there is always the temptation of being a decapitated Pelagian body. The fact that it is the woman and the Church who are enjoined specifically to "be subject" to and "respect" the head (v. 22, 24, 33) highlights their specific resistance to the novelty of Christianity: "what have you that you did not receive?" (I Corinthian 4: 7). ${ }^{118}$ This advice, in the first place, is for the woman. It is the condition for her to receive the love of the "savior of the body" (Ephesians 5: 23) ${ }^{119}$ Headship is also a necessary intervention for her poor children, who risk being trapped in a suffocating (oedipal) sphere of immanence. ${ }^{120}$ Ironically, notwithstanding all the typical prejudices and one-sided accounts of violence, headship is a question of restoring "equality" to the head for everyone's benefit.

\section{Part III: Absent Fathers: Radiation of Fatherhood}

What now can be said about headship from the perspective of the head? We have already glimpsed much of the answer to this in the foregoing. Here we will draw out only what remains to be

114 Commenting on this exclamation, Balthasar writes: "She understands that the human child is not a mere gift of nature but a personal gift of God" (Balthasar 1990, p. 372).

115 The father precisely by virtue of his being "outside" the process of conception, birth, and the early years of the child, calls the child to enter into a world at a distance from the mother, as well as the "distant" (transcendent) source of the world. Jose Granados writes: "What the father contributes is the appearance of a primordial separation in the world of the child. To be sure, the father is aware of the child's belonging to him, but he sees it as a distance that needs to be covered. This distance allows the child to grow in his encounter with the world and the understand his life as a journey toward transcendence" (Granados 2009, p. 195). On this point see also (Raab 2018, pp. 102-3).

116 We refer to the expression used by Teilhard de Chardin (and others) to speak to the woman as unifying creation with God, chiefly in Mary. See (de Lubac 1965, pp. 62-68).

117 The Pauline text about the "covering" ("sign of authority") women were to wear on their heads is much disputed, even as to the subject of the "authority" of which it is a sign. See (Rossetti 2003, p. 152; Fee 2014, pp. 567-80). In any event, the fact that the woman should wear the covering, is at the very least understood to be an outward sign of her married state, her relation to the man, something about which there appears to be some confusion in the Corinthian church. See (Wright 2004b, p. 142). See also (Balthasar 1989, p. 478). As to the particular source of the confusion, and the jettisoning of the "sign," there is little clarity. Does it come from an illegitimate conclusion made by neophytes that the natural relation between the sexes has been is surpassed in Christ? St. Paul's appeal to nature in v. 14 supports this view. Some have suggested influence from mystery cults. See (Rossetti 2003, "Vir Caput Mulieris'," p. 156).

118 It is true, of course, that all Christians are enjoined to "be subject to one another out of reverence for Christ (Ephesians 5: 21). Moreover, that enjoinder is either just prior to or the very beginning of "household code" of Ephesians 5 . John Paul II who takes verse 21 to be the beginning of the "household code" made much of the "mutual subjection" of man and woman. See n. 15 , above. We do not dispute this. What we note here, however, is that the mutual subjection between husband and wife is differentiated, according to two distinct manners, namely that of the head and the body. Moreover, the additional use of "subjection" for the wife, then the Church, suggests something about the subjection characteristic of the body, namely the acknowledgement (and "respect") of what is beyond just her, something that, in the state of sin, is contested by the woman (and the Church). We note too, that the admonition is repeated in Colossians 3: 18 and in I Peter 3: 6.

119 This is the interpretation John Paul II gives of the specific advice to wives to "be subject." "[T]he wife's 'submission' to the husband, understood in the context of the whole of Ephesians 5: 22-23, means above all 'the experiencing of love.' This is all the more so, because this 'submission' refers to the image of the submission of the Church to Christ, which certainly consists in experiencing his love. The Church as Bride, being the object of the redemptive love of Christ, the Bridegroom, becomes his body." The wife, being the object of the spousal love of her husband, becomes 'one flesh' with him: In some sense, his 'own' flesh." (John Paul II 2006, p. 485).

120 The teaching on the immediate creation of the soul is surely relevant here for the "distinction" of the child from the mother (and the father) and its corresponding value. See Lateran Council V (1513): DS 1440; The Catechism of the Catholic Church, 366. 
stated. The first thing to note is that every head, except for God the Father has a head. Only one is source in the absolute sense as "Origin without origin." The others are not and owe themselves to Him. Thus, they are heads first as sons. ${ }^{121}$ Further, with respect to that of which they are head, they are not "father," but rather "bridegroom." John Paul II's meditation on the "original solitude" of Adam before sexual differentiation means to highlight this point. Adam is first son. ${ }^{122}$ The relevance of this for the "woman," as we noted, is that the reference back to a headship in God himself establishes the ground for her utter positivity, precisely in her distinction from the head. She is not just the "world" of which God the Creator is "head," now played out in her relation to the man. The fact of his prior sonship makes reference to a more basic relation in God himself, which then grounds the world. His headship is founded on the sonship of Christ, who is "the head of very man" and of "all things." And, of course, the head of the Body/Church is this same Christ. The relevance of this for the head himself is that he is not an absolute. What he offers as head, therefore is derived from and in partnership with Another behind him so to speak. ${ }^{123}$ Yet, of course, because of that reference he too can become a father together with the body-bride (woman-Church). ${ }^{124}$

Secondly, the head in the Christian account, and in every case, is always already determined by the "second," be it the Eternal Son, be it the body-bride (woman/Church). The head, is never, either in the logical or temporal sense, "first" in the solitary, or absolute sense. The word on the "first' human being in the garden is crucial here: "it is not good that the man should be alone." The same can be said of the New Adam as well. As God, of course, he does not need the Church-Bride, but as man he does, even to become man. So too the first Person in the Trinity is always already determined by His relation to the Son, since the first Person is Father. ${ }^{125}$ Feminists often rightly critique the enclosed "masculine" aseity of God and his created (male) image. ${ }^{126}$ However, this has nothing to do with the Christian God whose absoluteness is triune absoluteness, even when it concerns the Father, who as Father is also never alone. Thus too, for the created (male) image, he is never fully himself by himself. Indeed, in Genesis 2 he is not 'î̌ until woman ('išša $)$ appears. ${ }^{127}$ In this sense then, what comes "after," has nothing to do with being "secondary," or a "second thought." On the contrary, it is always latent within first (the "rib"). It was always the case, in other words, that he was determined by the woman. ${ }^{28}$ The fullness of things is already in the very beginning. He was never alone, strictly speaking. Consequently, as Balthasar

121 This point is relevant for any discussion of the "super-sexuality" in God. See note 109, above. It establishes that prior to any "nuptial" dimension in God there is first paternity and sonship. As Louis Bouyer writes: "[S]exuality is transcended in God, or rather anticipated, not in asexuality-even less in bisexuality-but in a fatherhood and sonship which transcend the opposition of the sexes" (Bouyer 1979, p. 37). By observing this primacy, we would resist, then, the analogy often made by Balthasar between the Father and the Son and Adam and Eve, or Christ and the Church, where the Son is the "feminine," and Adam the creaturely analogy of the father, and Eve of the son. See e.g., (Balthasar 2014, p. 170).

122 See note 14 , above.

123 We can distinguish this derivation at the level of nature and grace. On the one hand, the man's contribution in procreation is both a real contribution and a secondary sharing in God's creative power, which is immediate by contrast to His causal presence with other secondary natural causes. See Aquinas, ST, I, 90. 3. On the other hand, the "capital grace" of Jesus Christ bestowed on the Church is the same habitual grace bestowed on the soul of Jesus by God. See Aquinas, ST, III, 7.1.

124 In early Christianity, the title "Father" was applied to Christ because Christ represented and made visible the paternity of the Father, and generated, through his death and resurrection, a new humanity. This possibility appears already in the Old Testament: "For to us a child is born ... and his name will be called ... Everlasting Father" (Isaiah 9: 6). See (Granados 2009, pp. 197-205).

125 Balthasar thinks this out in terms of actus purus. The Father begets and is thus "active actio." ("letting go"). The Son is begotten and is "active passio" ("letting be"). Since the "letting be" is the "condition" of the "letting go," it is no less eternal. See (Balthasar 1998, Theo-Drama, vol. V, pp. 85-91). Balthasar, however, qualifies the "being determined" by the other as "supra-feminine." Thus, the Father, as determined by the Son, is "super-feminine (ibid., 91). In my view, this is a mistake for two reasons. First, it identifies sexual difference with attributes that do not go to the essence of the difference, the attributes of "giving and receiving" or "determining and being determined." Then, when it comes to fatherhood, which (like motherhood) does go to the essence of sexual difference, it seems to diminish the Christian word on it. The Father is Father, precisely by virtue of the fact that He is always already by determined by the Son, even as He is His Origin. He does not slip into the "feminine" by being so determined. It is part of what it means to be Father. See also note 109, above.

126 See for example (Hampson 1996, p. 124).

127 See note 14 , above.

128 John Paul the II meditated on the receiving dimension of giving in terms of "welcoming" and "being entrusted with." See (John Paul II 2006, p. 187; 2014, pp. 873-75). 
writes: "[T]his banishes the idea of a primal, androgynous human being, supposedly originally at peace with himself and only subject to unsatisfied longing after being split into two sexes." ${ }^{129}$ Further, for the woman, it banishes the idea of a decent from something more perfect. On the contrary, woman is his fulfillment (in the sense that, with her, the humanum, as a community, is brought to completion). She is, as it were, his "future." ${ }^{130}$ In this second sense, then, he is not an absolute.

Thirdly, for Christ and the Christian husband, the fulfillment that their "bodies" brings to them as head is surprising and new, not the "same old sameness," the woman being in some sense reduced to, and under the control of, the "first," as some feminists insist she must if she comes from the man. ${ }^{131}$ Recall de Beauvoir's concern that the woman is brought forth to confirm the man's essentiality, through her in-essentiality, and his freedom through her docility. Balthasar, who insisted on the "persistent priority" of the man and the derivation of the woman "from his side," was well aware of these objections. ${ }^{132}$ Thus, when he comments on the Biblical account he notes:

"It is through being overpowered in a "deep sleep" and robbed of part of himself, near to his heart, that man is given fulfillment ... the man retains a primacy while at the same time, at God's instigation, he steps down from it in a kenosis: this results in the God-given fulfillment whereby he recognizes himself in the gift of the 'other'."133

Although, however "latent" the woman is in the first man, she is not simply produced by him. Rather, she is given to him "from above," when he is "asleep," and therefore according to the "positivity of the other" in God Himself. In this sense, she is both new (surprising) and thoroughly positive. Moreover, when she comes also "from within," she comes by way of his expropriation, in which case he is carried "over there," so to speak, and not only to a separate body distinct from his, but to an unexpected different one, a "bridely" one. Since, then, that body is "his own flesh" (Ephesians 5: 28-29), he now can only find himself "ecstatically," by way of a unity higher than the one he had with himself. "[T]hrough the loss of what seemed to be oneness, [he] finds this oneness with and in the other."134 In view of this account, the woman can hardly be said to be "under his control." On the contrary: "the husband does not rule over his own body, but the wife does." Or rather, they both are under each other's "control": "the wife does not rule over her own body, but the husband does" (I Corinthians 7: 4).

The woman's new, positive, and "uncontrollable" otherness is also found in the fact that she has her own principle of fruitfulness. She is not just an empty vessel. ${ }^{135}$ Thus, if she must refer to a principle, which generates outside himself, it is not the case that he meets an empty "receptacle" (as in

129 (Balthasar 1990, Theo-Drama, vol. II, p. 373).

130 (John Paul II 2014, "Meditation on Givenness," p. 874). On this point, I am indebted to Deborah Savage who writes: "the fact that Eve is created second is not to make her subservient. She is, in fact, made on the way up - the last creature to appear, a creature made, not from earth, but from Adam, that is, from something that arguably already contains a greater degree of actualization than dust or clay. It does seem as though she is made of "finer stuff." In any case, because of the order suggested by reading the accounts together, Eve can be seen as the pinnacle of creation, not as a creature whose place in that order is subservient or somehow less in stature than that of Adam. For with her creation, human community appears for the first time-and enters into human history. Without man, woman has no place. However, without woman, man has no future. See (Savage 2020).

131 Post-modern feminists criticize Balthasar for his "one-sex" model (notwithstanding his language to the contrary) on account of the importance he gives to the derivation of the woman from the man, the "persistent priority" of the latter. See (Crammer 2004, "One sex or two? Balthasar's theology of the sexes," p. 102); (Moss and Gardner 1998, "Difference-The Immaculate Concept? The Laws of Sexual Difference in the Theology of Hans Urs von Balthasar," p. 384).

132 Balthasar is quite conscious of these Hegelian possibilities in his discussion of the relation between the subject and the object (Balthasar 2000, pp. 35-78). He writes: "It is not true that in order to attain self-knowledge, the ego, acting out of some sort of freedom, sets a non-ego over against itself, in order to regain itself from the other's point of view .... .In fact, the contrary is true: the most marked index of the finite subject's creaturehood is the fact that it is already serving before it awakens to itself as subject. It awakens in the act of service, and henceforth it will awaken to itself in the measure that it serves in an attitude of self-forgetfulness" (ibid., p. 71). For Balthasar, the "self-forgetful service" of the "subject" owes itself to the fact that the "subject" awakens to itself within an already occurring engagement with the "object," by which its "doors have already been beaten down," "without prior invitation," (ibid., p. 68).

133 (Balthasar 1990, Theo-Drama, vol. II, p. 373). See also (Balthasar 1992, p. 285).

134 (Balthasar 1983, pp. 245-46). See also Hans Urs Balthasar, Ephesians 5: 21-33 (Dennehy 1981, p. 67).

135 (Balthasar 1992, p. 285). 
the Timaeus), which guarantees him an exact replica of himself. On the contrary, by virtue of her own principle of fruitfulness, she brings forth something new and surprising to the man. "[T] he woman does not merely give back to man what she has received from him: she gives him something new, something that integrates the gift he gave her but that 'faces' him in a totally new and unexpected form." 136 Is this not also true for God Himself (once He freely creates the world in view of Christ's incarnate headship of it and of His Body, and once it has been established that this "newness" for God is an expression of the eternal "positivity of the other" already in God)? ${ }^{137}$ Does Mary not give to God something new as mother of the Incarnate Son ${ }^{138}$ Neither a more positive account of the feminine "other," nor a humbler account of the head could be imagined! "Woman is not independent of man nor man of woman."

There is a fourth and final feature about headship for the head. It is the implication of his non-absolute identity. It concerns what the head does. It is simply this: To be a father. This means in the first place, that the head place his power at the service of giving life. Here, the Christian account of God directly affects a conception of power, for there, omnipotence is precisely the power of generation, the reason for which the Father (the Head) "appropriates" it. ${ }^{139}$ We might still hear the ring of this in the ancient term "authority" (auctoritas), which has at its root the idea of "making grow" (augere). What we see here is that generation is not a mere "channeling" of power ("using it for good"); it is its very essence, contrary to the uniformly absolutist and violent notions (and uses) of it in modernity. ${ }^{140}$ To be a head in the Christian sense, then, is to be a father, or, more accurately for the head who is first a son, to "radiate" the fatherhood of God. ${ }^{141}$ The Son does this by handing his divine humanity over to his Bride, the Church, re-creating her ("by the washing of water") making her capable of being the mother of the living in a new and deeper sense (in the way He did His own mother, conceived "full of grace"). The Christian husband, obviously, neither creates nor re-creates his wife, and he is first born of his mother ${ }^{142}$; but he still lives and acts ("giving himself up for her," "loving her as himself") in the shadow of the "mystery" of Christ's love for the Church. Giving not only himself, he can be together with her, become father in view of a new and deeper Life.

In the second place, this means that the head take ownership of and responsibility for what He generates, allowing his name to be associated with the begotten. It is to "be involved." 143 In God,

136 (Balthasar 1992, p. 285).

137 We suggest that the "nuptial" dimension is something that appears first in relation to the world, beginning with the reference to Israel as "bride" (Hosea 2: 20) and culminating in Christ's relation to the Church-Bride. It would therefore belong to the novelty of the world (for God), together with materiality, even as the possibility for these arise from the Paternal-filial "positivity of the other" in God.

138 In his striking Homily on the Annunciation, Nicholas Cabasilas speaks to the generosity of God in letting the creature give something to God. "At one and the same time, he bestows benefits on the creation out of his own spontaneous largesse and he receives something from creation as well. For this reason, he does not take greater joy in giving great gifts (which is the expression of his munificence) than in receiving small gifts from those whom he has benefitted (which is the expression of his love for mankind), thus getting honor for himself, not only by what he has conferred on his poor servants, but also by what he has gladly received from these same poor servants!" Cf. "Homily on the Annunciation," in Communio, vol. 46.2 (Summer, 2019), 387. See also Paolo Prosperi's exquisite commentary on Cabasilas' Homily, "'Fixed End of the Eternal Plan': 'Homily on the Annunciation'," in (Prosperi 2019, pp. 207-36). One can see the same bold claim in the words Dante puts into St. Bernard when addressing Mary: "she who so ennobled human nature that its Creator did not disdain to be made its creature" (Dante 2004, Paradiso, XXXIII, 1-6).

139 See (Aquinas 1952, De Potentia Dei, Q. 2. 5-6).

140 See Augosto Del Noce's masterful account of the notion "power" in modernity against the backdrop of its antecedent, "authority" in (Del Noce 2014, pp. 190-246).

141 The term is used by Karol Wojtyła in his play "Radiation of Fatherhood." See (Wojtyła 1987, pp. 335-68).

142 See note 101 above. Balthasar, commenting on L. Bouyer, writes: Is it really impossible to ascribe to Christ with regard to the Church a role which is as ephemeral as that played by the man as a sexual being with regard to the woman? The author is, of course, aware of this, and he comes to terms with it in two ways. The Church, on the one hand, is the body formed by Christ the Head and proceeding from within him. She is the coming-into-view of the fulness of Christ, who in this 'body' or 'bride' fashions his own fullness for himself. On the other hand, to do this is possible for him only because, as Bouyer says, the Son in the world is the sole fully valid representative of the only fatherhood perfectly deserving the name: the paternity of the eternal Father who begets the Son in one uninterrupted act and who, together with the Son and the Spirit, creates and sustains the world in just as continuous a manner" ("Epilogue," in Bouyer 1979, pp. 115-16).

143 See note 97 , above. 
this is most manifest in the fact that His very name betokens His relation to the Son. When, then, He creates the world, through the Son, His "involvement" becomes manifest in His willingness to be our Father, to the point of joining His divinity permanently to our humanity in His Son and then letting that divine-humanity be expropriated to another "body," which the Incarnate Sonidentifies "as himself." For the husband, it is a question of doing the same, binding himself to his wife and to the children as his, so that they can be Christ's.

At the human level, the last feature of headship-"ownership"-is perhaps the most misunderstood in a culture that thinks of fatherhood only in terms of sheer power. On the contrary, for the man who stands at a distance from what he begets, "ownership" is, in the first instance, the choice to be bound. Karol Wojtyła's theatrical meditation on fatherhood, "The Radiation of Fatherhood," focusses precisely on this problem. There, "Adam" resists the word "mine" because he resists being a father. He wants to "throw the word out of his vocabulary" because it draws him into a "face to face" both with his daughter and with his own (divine) Father. ${ }^{144}$ The giving of the man's name to his wife and their children, or directly to their children, ought to be understood in this light as well, instead of as an exercise of power and control. Indeed, the practice arose in cultures where fatherhood had begun to be discovered, and where the father was therefore expected to "own up to" to it. "It was a public testament that they were "his" and he was "theirs" and that he would "submit his personal feelings to the interests of the family tradition." ${ }^{146}$ Amy and Leon Kass, reflect on the meaning of the taking of the father's name:

The husband who gives his name to his bride in marriage is thus not just keeping his own; he is owning up to what it means to have been given a family and a family name by his own father-he is living out his destiny to be a father by saying yes to it in advance. And the wife does not so much surrender her name as she accepts the gift of his, given and received as a pledge of (among other things) loyal and responsible fatherhood for her children. A woman who refuses this gift is, whether she knows it or not, tacitly refusing the promised devotion or, worse, expressing her suspicions about her groom's trustworthiness as a husband and prospective father. Patrilineal surnames are, in truth, less a sign of paternal prerogative than of paternal duty and professed commitment, reinforced psychologically by gratifying the father's vanity in the perpetuation of his name and by offering this nominal incentive to do his duty both to mother and child. ${ }^{147}$

Just as headship is a correction of the woman's worst tendencies, so too is headship a correction of the man's worst tendencies. We have just suggested the tendency to absolutism, to which the charge to "love their wives as their own bodies" (Ephesians 5: 28) appears to be the antidote. Headship enjoins the head to call their wives (and eventual children) "mine," and to be "theirs," in turn. It counteracts the distinctly male cartesian "flight from the world" (and the woman), which takes the concrete form of the refusal to be "tied down" to a woman, then infidelity to her, and the subsequent neglect of their children. ${ }^{148}$

However, headship can only do this by countering the more radical temptation to absolutism, namely of being "like God," without God, according to a counterfeit image of God. It does just this by enjoining the husband to turn to Christ the head, who is Son of the Father. By acknowledging that he is not the Father, but radiates His fatherhood, the Christian father acknowledges that his child is not simply his (a res patris) over whom he has the right to decide whether he lives or dies (according

\footnotetext{
144 Karol Wojtyła, “Radiation of Fatherhood," (Wojtyła 1987, 337, 339, 355).

145 See Miller, "Origins of the Father-Involved Family," (Miller 1999, pp. 11-17, 120-24).

146 Dawson, Enquiries into Religion and Culture, 225. There is a corresponding "burden" placed on the woman in "patriarchy," namely chastity before marriage. It guarantees the "certitude" of paternity.

147 (Kass and Kass 2000, p. 541).

148 On the masculine character of the "flight from the world" characteristic of modernity, see (Bordo 1987; Stern 1965).
} 
to the patria potestas). ${ }^{149}$ On the contrary, he is to "bring them up" and do so "in the discipline and instruction of the Lord" (Ephesians 6: 4). They are to be referred to the Lord, who, for His part, is "about his Father's business" (Luke 2: 49). A father's children, in other words, are not to be taken as mere extensions of himself, brought into the world to carry on his work. Or rather, his children are to carry on his business as it "radiates" God's "business." Here, we can see the theological meaning of "being subject to" as it pertains to the head himself. He is "subject to" the Father so that "God can be all in all" (I Corinthians 15: 28).

By virtue of the head's reference to the Father, Christian headship also counters the "negativity of the other" (misogyny) at the heart of which is the downgrading of the value of the female body (including now, the temporary use of it for breeding). With headship, the head must acknowledge that his power is coordinated reciprocally with the power of the "body," beginning with her equal part in generation, and then the rule and management of the home, of which she is, biblically speaking,

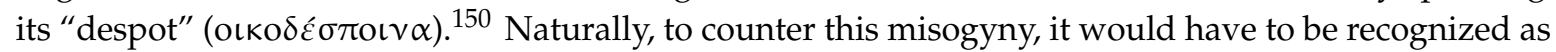
such (even if so many women are complicit in it) and remedied with an affirmation of the positivity of motherhood and the value of the home for society.

To this aspect of the "correction" we could add the ecclesial correlate. Headship reminds the "petrine dimension" that what it transmits to the "marian dimension" is not strictly its own. ${ }^{151}$ It acts "in persona Christi capitis." The Church is Christ's bride, and "Peter" exists to guarantee that she and her children always be His. Peter must serve that and not do with the Church as he wills, "lording it over her" (Matthew 20: 25). ${ }^{152}$ Secondly, headship corrects "Peter's" clericalism which would reduce the Church to his dimension alone. By acting "in persona Christi capitis," "Peter" is meant to see his ministerial priesthood as coordinated with the distinct common priesthood (of "Mary") without which what he offers would find no home in the world, the secular sphere, where "Mary" rules. ${ }^{153}$ Without her, "Peter" would be sterile, and have nothing new to offer back to the Father together with the body of the Lord. ${ }^{154}$ Here too, though, ecclesial "misogyny" is found not only on "Peter's" side, but also on "Mary's," with all of the demands by lay persons themselves for positions "in the Church" as if they were not already in it, at the heart of the world. Much needed, is the recovery of the value placed on the laity being there, by God Himself!

\section{Conclusions}

I have argued that the biblical category of "headship" concerns nothing less than the novel understanding of the world's relation to God that accompanied the revelation of the God of Jesus Christ, even when it was brought to bear on apparently small practical and internal issues. I have

149 See note 120 above. On the point of derivative fatherhood, L. Bouyer writes: "the masculinity of man only expresses itself in man as a trait not only derivative but borrowed, and never wholly realizable in him. Even on the physical, natural plane, to say nothing of the supernatural, man will never be more than a father by proxy, in a sense, nor will the whole-even what is in fact essential — of fatherhood ever be in him. There is only one father who is entirely a father, and that is God" (Bouyer 1979, p. 35).

150 In I Timothy, there is an interesting pair of words. The husband must manage ( $\pi \rho 0$ ö $\tau \tau \alpha \mu \varepsilon v o v)$ his household (I Timothy 3:

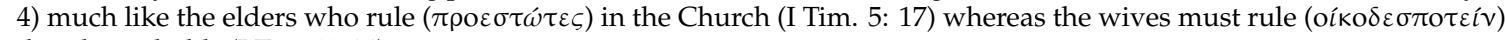
their households (I Tim. 5: 14).

151 Balthasar used the "Petrine and Marian" dimensions to refer to the relation between the two priesthoods, the "ministerial" and the "common" (the laity) in the Church. See (Balthasar 1992, pp. 351-60; 1986a, pp. 204-25; 1991, pp. 157-72; 1975, pp. 64-72). The distinction was used subsequently by John Paul II used it subsequently in Mulieris Dignitatem (27) and the Catechism of the Catholic Church (773).

152 Balthasar writes: "The event in which the Church is 'born' from Christ is a continual event, happening here and now. The abiding structure of offices in the Church (the 'institution') means that we are guaranteed the possibility of participating in the original event at any and every time" (Balthasar 1992, p. 355).

153 Lumen Gentium, 31. Christifideles Laici, 15 (John Paul II 1988b).

154 Referring to the works, prayers, apostolic undertakings, family and married life, daily work and relaxation of the laity, Lumen Gentium says: "In the celebration of the Eucharist these may most fittingly be offered to the Father along with the body of the Lord. And so, worshipping everywhere by their holy actions, the laity consecrate the world itself to God" (Lumen Gentium, 34). 
argued, moreover, that, contrary to common assumptions of much of feminism, ordered difference, on the Christian account, is not only not contrary to equality, but coincident with it where the equal subjects in question are more than interchangeably the same-or differently estranged-but belong to each other in a relation of reciprocal, fruitful unity and positive (equal) distinction. To suggest otherwise is simply to lose sight of all the radical newness of Christian revelation-about God in the first instance-and fall back into the same restrictive subordinationist patterns of thought that afflicted Christianity in its earliest centuries, limited as they were by the worldly alternatives of indifferent sameness and unequal difference. It is to deprive oneself of the very condition for a positive (equal) account of the difference between man and woman. From the point of view of Catholic theology, much of feminist theology does just this.

To summarize, that novelty consists in a unity in difference, marked by a generous origin, and the "positivity of the other" on account of which both the "first" and the "second" are themselves by an "original unity" with the other. The God of Jesus Christ is the Father of a Son, who is equal with the Father in divinity by virtue of his coming from Him (through generation). At the same time, the Father, being Father, is always already determined by the Son. They are reciprocally and equally dependent upon each other in order to be what they are. This God, then, without necessity, is also the Creator of the world which now, for the first time in the history of thought, is a "good creation" - and as distinct from God-because it is an expression ad extra of the positivity of the other in God. It is that distinction that is expressed in the relation between man and woman at the beginning of creation and Christ and the Church in the New Creation. In each case, worldly "headship" is a question of acknowledging a transcendent source of the life, for the "body," and the "being involved with" and determined by, the body, for the head.

Headship, as we said, is not always between equals, even when it is between subjects who share a common nature (as with Christ and "all things" and Christ and the Church). However, it is not by virtue of headship per se, that this is so, but rather by virtue of the distinction between God and the world. Worldly headship does bear that "vertical" distinction, since it bears the transcendent source and origin of life (and new Life). Nevertheless, even that distinction is rooted in a more primordial "horizontal" one, given in God himself: The original (good and fruitful) unity in distinction of equals, founded on generosity. It is, as St. Bonaventure said, because there is a production of something equal in God, that there can be an (unequal) world over which Christ is head in the first place. ${ }^{155}$ Thus, even the inequality between creature and Creator reflects, as through a glass darkly, the equality of the divine persons-not as lack of difference, but as abundant differentiation as ordered community. What is more though, is the Son's radiation into the world of the boundless generosity of the original headship when $\mathrm{He}$ "not grasping at" his equality with the Father was born in the world, of a woman, to receive something new from her-his "likeness of men"- then conferred upon that likeness a share in his "likeness to God," his equality with the Father.

It is within this context that we can see the full scope of headship as it applies to man and woman. Put negatively, headship counters the "body's" default "certainty" about her "natural" and exclusive life-giving power, enjoining her to be "subject" to a "first love." In so doing, it restores equality to the head while guaranteeing a positive account of the "body" and some "space" for her child. For the "head," it counters the false absolutist image of God and of his power (manifest in the use, abuse, neglect, and deprecation of the other/woman). It enjoins him to "radiate" something of which he is first "subject" to the woman (and their child) recognizing in her something necessary to him, as positive and as other. It is the establishment of equality for the woman. Put positively, headship simply identifies the deep-seated original unity between distinct and equal subjects who belong to each other by virtue of a generous order of giving and receiving and receiving and giving back: "[W]oman is not independent of man nor man of woman; for as woman was made from man, so man is now born of woman" (I Cor.

155 See note 106 above. 
11: 11-12). It does this as it looks to another unity, that of the "Great Mystery," and the Divine unity itself, which makes it possible that there even be a not-God to which God could turn and be "all in all."

Funding: This research received no external funding.

Acknowledgments: The author is especially grateful to her colleagues, Joseph Atkinson and Adrian Walker, for their expert theological advice on certain aspects of this paper. In this section you can acknowledge any support given which is not covered by the author contribution or funding sections. This may include administrative and technical support, or donations in kind (e.g., materials used for experiments).

Conflicts of Interest: The author declares no conflict of interest.

\section{References}

Aeschylus. 1953. Oresteia. Translated by R. Lattimore. Chicago: The University of Chicago Press.

Allen, Prudence. 2016. The Concept of Woman, Vol. III: The Search for Communion of Persons, 1500-2015. Grand Rapids: William B. Eerdmans Publishing Company.

Aquinas, Thomas. 1952. Quaestiones Disputatae De Potentia Dei. On the Power of God. Translated by the English Dominican Fathers. Westminster: The Newman Press.

Aristotle. 1999. Metaphysics. Translated by Joe Sachs. Santa Fe: Green Lion Press.

Atkinson, Joseph. 2014. Biblical and Theological Foundations of the Family: The Domestic Church. Washington, DC: The Catholic University of America Press.

Balthasar, Hans Urs. 1933. My Work in Retrospect. San Francisco: Ignatius Press.

Balthasar, Hans Urs. 1968. Man in History—A Theological Study. London: Sheed and Ward, pp. 313-14.

Balthasar, Hans Urs. 1975. The Marian Principle. In Elucidations. London: SPCK.

Balthasar, Hans Urs. 1983. The Christian State of Life. Translated by Mary F. McCarthy. San Francisco: Ignatius Press.

Balthasar, Hans Urs. 1986a. The Office of Peter and the Structure of the Church. Translated by Andrée Emery. San Francisco: Ignatius Press.

Balthasar, Hans Urs. 1986b. Women Priests. In New Elucidations. Translated by M. T. Skerry. San Francisco: Ignatius Press, pp. 187-98.

Balthasar, Hans Urs. 1989. The Glory of the Lord, Vol. VII: Theology: The New Covenant. Translated by Brian McNeil. San Francisco: Ignatius Press.

Balthasar, Hans Urs. 1990. Theo-Drama. Vol. II: Dramatis Personae: Man in God. Translated by Graham Harrison. San Francisco: Ignatius Press.

Balthasar, Hans Urs. 1991. Explorations in Theology, Vol. II: Spouse of the Word. Translated by A. V. Littledale. San Francisco: Ignatius Press.

Balthasar, Hans Urs. 1992. Theo-Drama, Vol. III: The Dramatis Personae: The Person in Christ. Translated by Graham Harrison. San Francisco: Ignatius Press.

Balthasar, Hans Urs. 1998. Theo-Drama, V: The Last Act. Translated by Graham Harrison. San Francisco: Ignatius Press, pp. 85-86.

Balthasar, Hans Urs. 2000. Theo-Logic, Vol. I: Truth of the World. Translated by Adrian Walker. San Francisco: Ignatius Press.

Balthasar, Hans Urs. 2014. The Dignity of Woman. In Explorations in Theology, Vol. V: Man Is Created. Translated by Adrian Walker. San Francisco: Ignatius Press.

Beattie, Tina. 1998. A Man and Three Women: Hans, Adrienne, Mary and Luce. New Blackfriars 79: 97-103. [CrossRef]

Bonsirven, Joseph. 1963. The Theology of the New Testament. Westminster: The Newman Press.

Bordo, Susan R. 1987. The Flight to Objectivity-Essay on Cartesianism \& Culture. Albany: State University of New York Press.

Bouyer, Louis. 1979. Woman in the Church. Translated by Marilyn Teichert. San Francisco: Ignatius Press.

Buckley, Jorunn Jacobsen. 1986. Female Fault and Fulfilment in Gnosticism. Chapel Hill: University of North Carolina Press.

Butler, Sara. 1996. Priestly Identity: 'Sacrament' of Christ the Head. Worship 70: 290-306. 
Cerfaux, Lucien. 1959. The Church in the Theology of St. Paul. Translated by Geoffrey Webb, and Adrian Walker. New York: Herder and Herder.

Cervin, Richard S. 2016. On the Significance of Kephalē ("Head"): A Study of the Abuse of One Greek Word. Available online: https://www.cbeinternational.org/resources/article/priscilla-papers/significance-kephal\% C4\%93-\%E2\%80\%9Chead\%E2\%80\%9D (accessed on 12 June 2020).

Chesterton, Gilbert Keith. 1990. The Equality of Sexlessness. In Brave New Family. San Francisco: Ignatius Press, p. 101.

Childs, Brevard S. 1985. Old Testament Theology in a Canonical Context. Philadelphia: Fortress Press, pp. 189-94.

Christ, Carol P. 2002. Feminist theology as post-traditional theology. In The Cambridge Companion to Feminist Theology. Edited by S. F. Parsons. Cambridge: Cambridge University Press.

Congar, Yves. 2018. I Believe in the Holy Spirit. Edited by Geoffrey Chapman. New York: The Crossroad Publishing Co.

Crammer, Corinne. 2004. One sex or two? Balthasar's theology of the sexes. Edited by Oakes. In The Cambridge Companion to Hans Urs von Balthasar. Cambridge: Cambridge University Press, pp. 93-112.

Dante. 2004. Paradise. Translated and edited by Anthony Esolen. New York: The Modern Library.

Davis, Elizabeth Gould. 1971. The First Sex. New York: G. P. Putnam's Sons.

Dawson, Christopher. 2009. Enquiries into Religion and Culture. Washington, DC: The Catholic University of America Press.

De Beauvoir, Simone. 2011. The Second Sex. Translated by Constance Borde, and Sheila Malovany-Chevallier. New York: Vintage Books. First published 1949.

de Cortázar, Blanca Castilla. 2017. La Persona Humana y la Diferencia Sexual: Prospectivas Filosóficas. In Ruolo Delle Donne Nella Chiesa-Atti del Simposio promosso dalla Congregazione per la Dottrina della Fede. Città del Vaticano: Libreria Editrice Vaticana.

de Lubac, Henri. 1965. Teilhard de Chardin: The Man and His Meaning. Translated by René Hague. New York: Hawthorn Books, Inc.

Del Noce, Augosto. 2014. The Crisis of Modernity. Translated by Carlo Lancellotti. Montreal: McGill Queen's University Press.

Dennehy, Raymond, ed. 1981. Humanae Vitae: A Meditation. In Christian Married Love. San Francisco: Ignatius Press.

Elshtain, Jean Bethke. 1981. Public Man, Private Woman. Princeton: University of Princeton Press.

Fee, Gordon D. 2014. The First Epistle to the Corinthians. Grand Rapids: William B. Eerdmans Publishing Company.

Gimbutas, Marija. 1991. The Language of the Goddess. San Francisco: Harper.

Gonzalez, Michelle. 2004. Hans Urs von Balthasar and Contemporary Feminist Theology. Theological Studies 65: 566-95. [CrossRef]

Granados, José. 2009. Priesthood: A Sacrament of the Father. Communio 36: 188.

Greely, Henry T. 2016. The End of Sex and the Future of Reproduction. Cambridge: Harvard University Press.

Grosz, Elizabeth. 1995. Space, Time, and Perversion. New York: Routledge, pp. 45-57.

Hampson, Margaret Daphne. 1996. After Christianity. Valley Forge: Trinity International.

Hesiod, Apostolos N. Athanassakis. 1983. Hesiod, Theogony, Works and Days. Translated by A. Athanassakis. Baltimore: Johns Hopkins University Press.

Hook, Donald D., and Alvin F. Kimel Jr. 1993. The Pronouns of Deity: A Theolinguistic Critique of Feminist Proposals. Scottish Journal of Theology 46: 297-323. [CrossRef]

Hook, Donald D., and Alvin F. Kimel Jr. 1995. Calling God 'Father.' A Theolinguistic Analysis. Faith and Philosophy 12: 207-22.

Irigaray, Luce. 1986. Égales a Qui? In Elisabeth Schüssler Fiorenza. En Mémoire d'elle. Paris: Editions du Cerf, pp. 420-30.

John Paul II. 1964. Lumen Gentium. Available online: http://www.vatican.va/archive/hist_councils/ii_vatican_ council/documents/vat-ii_const_19641121_lumen-gentium_en.html (accessed on 15 June 2020).

John Paul II. 1988a. Mulieris Dignitatem. Available online: https://www.vatican.va/content/john-paul-ii/en/apost_ letters/1988/documents/hf_jp-ii_apl_19880815_mulieris-dignitatem.html (accessed on 15 June 2020).

John Paul II. 1988b. Available online: https:/www.vatican.va/content/john-paul-ii/en/apost_exhortations/ documents/hf_jp-ii_exh_30121988_christifideles-laici.html (accessed on 15 June 2020).

John Paul II. 1992. Catechism of the Catholic Church. Rome: Libreria Editrice Vaticana. 
John Paul II. 2006. Man and Woman He Created Them. A Theology of the Body. Translated by Michael Waldstein. Boston: Pauline Books and Media.

John Paul II. 2014. A Meditation on Givenness. Communio 41: 873-83.

Johnson, Elizabeth. 1992. She Who Is. New York: Crossroad, pp. 216, 219.

Jonas, Hans. 1963. The Gnostic Religion, 2nd ed. Boston: Beacon Press.

Kass, Amy, and Leon Kass. 2000. The Marriage Name. In Wing to Wing, Oar to Oar-Readings on Courting and Marrying. Notre Dame: University of Notre Dame Press.

Kereszty, Roch. 1999. God the Father. Communio 26: 261.

Keuls, Eva. 1993. The Reign of the Phallus: Sexual Politics in Ancient Athens, 2nd ed. Berkeley: University of California Press.

King, Karen L. 1988. Sophia and Christ in the Apocryphon of John. In Images of the Feminine in Gnosticism. Edited by Karen L. King. Philadelphia: Fortress.

Kroeger, Richard Clark, and Catherine Clark Kroeger. 1992. I Suffer Not a Woman: Rethinking I Timothy 2:11-15 in Light of Ancient Evidence. Grand Rapids: Baker House.

Lattimore, Richmond. 2007. The Odyssey. New York: Harper Perennial.

le Guillou, Marie-Joseph. 2009. The Name of the Father. Communio 36: 366-67.

Lewis, Clive Staples. 1960. The Four Loves. New York: Harcourt Brace Jovanovich, Inc.

Lewis, Clive Staples, and Robert Whitfield. 1946. The Great Divorce. New York: The Macmillan Company.

Loughlin, Gerard. 1999. Erotics: God's Sex. In Radical Orthodoxy: A New Theology. Edited by John Milbank, Catherine Pickstock and Graham Ward. New York: Routledge.

Malinowski, Bronislaw. 1927. The Father in Primitive Psychology. New York: W. W. Norton.

McFague, Sally. 1993. The Body of God: An Ecological Theology. Minneapolis: Fortress Press.

Miller, John W. 1999. Calling God Father. New York: Paulist Press.

Millet, Kate. 1969. Sexual Politics. Sheffield: Equinox Books.

Moss, David, and Lucy Gardner. 1998. Difference-The Immaculate Concept? The Laws of Sexual Difference in the Theology of Hans Urs von Balthasar. Modern Theology 14: 377-402. [CrossRef]

Ong, Walter. 1981. Fighting for Life: Contest, Sexuality, and Consciousness. Ithaca: Cornell University Press.

Oulton, John, and Henry Chadwick. 1954. Alexandrian Christianity. Philadelphia: The Westminster Press.

Pagels, Elaine. 1979. The Gnostic Gospels. New York: Random House.

Prosperi, Paolo. 2019. 'Fixed End of the Eternal Plan': 'Homily on the Annunciation'. Communio 46: 207-36.

Raab, Christian. 2018. In Search of Masculine Genius. The Contribution of Walter J. Ong. Logos 21: 83-117. [CrossRef]

Ramsay, William M. 1895. Cities and Bishoprics of Phrygia. Oxford: Clarendon.

Ratzinger, Joseph. 1983. Daughter Zion: Meditations on the Church's Marian Belief. Translated by John M. McDermott. San Francisco: Ignatius Press.

Ratzinger, Joseph. 2007. Jesus of Nazareth, From the Baptism in the Jordan to the Transfiguration. Translated by Adrian Walker. New York: Doubleday.

Roberts, Alexander D. D., and James Donaldson, eds. 2010. The Complete English Translation from the Fist Volume of the Ante-Nicene Fathers. San Bernadino: Ex Fontibus Co.

Rossetti, Carlo Lorenzo. 2003. 'Vir Caput Mulieris' (I Cor 11,3-Ef 5, 22)? Indagine teologica sul senso di una metafora circa il rapporto uomo-donna. Anthropotes 19: 152.

Rowe, Joseph. 2005. The Gospel of Thomas. Rochester: Inner Traditions.

Savage, Deborah. 2020. Woman and Man: Identity, Genius, and Mission. In The Complementarity of Women and Men: Philosophy, Theology, Psychology, and Art. Edited by P. Vitz. Washington, DC: The Catholic University Press, chp. 3.

Schindler, David L. 2008. The Embodied Person as Gift and the Cultural Task in America: Status Quaestionis. Communio 35: 397-431.

Schindler, David C. 2019. The Exclusivity of Gender and the Gift of Motherhood. Communio 46: 261-63.

Schlier, Heinrich. 1965. Theological Dictionary of the New Testament, vol. III: $\theta-\kappa$. Edited by Gerhard Kittel. Grand Rapids: Wm. B. Eerdmans Publishing Company, pp. 673-82.

Schlier, Heinrich. 1968. Essais sur le Nouveau Testament. Translated by A. Liefooghe. Paris: Les Édition du Cerf.

Schmitz, Kenneth. 1982. The Gift: Creation. Milwaukee: Marquette University Press.

Schüssler-Fiorenza, Elizabeth. 1994. In Memory of Her. New York: Crossroad. 
Stern, Karl. 1965. The Flight from Woman. New York: Farrar, Straus and Giroux.

Turner, John Douglas, and Anne Marie McGuire, eds. 1997. The Primal Triad in the Apocryphon of John. In The Nag Hammadi Library after Fifty Years: Proceedings of the 1995 Society of Biblical Literature Commemoration. Leiden: Brill.

Walker, Adrian J. 2004. Personal singularity and the communio personarum: A creative development of Thomas Aquinas' doctrine of esse commune. Communio 31: 457-80.

Wojtyła, Karol. 1987. The Collected Plays and Writings on Theatre. Translated by Boleslaw Taborski. Berkeley: University of California Press.

Wright, Nicholas Thomas. 2004a. 'Men, Women and the Church' St John's College. Available online: http: //ntwrightpage.com/2016/07/12/womens-service-in-the-church-the-biblical-basis/ (accessed on 12 June 2020). Wright, Nicholas Thomas. 2004b. Paul for Everyone-I Corinthians. Louisville: Westminster John Knox Press.

Wright, Nicholas Thomas. 2006. The Biblical Basis for Women's Service in the Church. Priscilla Papers 20: 5-10.

(C) 2020 by the author. Licensee MDPI, Basel, Switzerland. This article is an open access article distributed under the terms and conditions of the Creative Commons Attribution (CC BY) license (http://creativecommons.org/licenses/by/4.0/). 